\title{
Structure and vibrational spectra of 2,5-diiodothiophene: a model for polythiophene
}

\author{
Stewart F. Parker, Jack L. Parker and Marek Jura
}

\section{Published version information}

Citation: SF Parker, JL Parker and M Jura. "Structure and vibrational spectra of 2,5diiodothiophene: a model for polythiophene."Journal of Physical Chemistry C, vol. 121, no. 23 (2017): 12636-12642.

DOI: $\underline{10.1021 / a c s . j p c c .7 b 03803}$

This document is the unedited author's version of a Submitted Work that was subsequently accepted for publication in Journal of Physical Chemistry C, (C) 2017 American Chemical Society, after peer review. To access the final edited and published work see DOI above.

Please cite only the published version using the reference above. This is the citation assigned by the publisher at the time of issuing the AAM. Please check the publisher's website for any updates. 


\title{
Structure and Vibrational Spectra of 2,5-Diiodothiophene: a Model for Polythiophene.
}

\author{
Stewart F. Parker,* Jack L. Parker and Marek Jura \\ ISIS Facility, STFC Rutherford Appleton Laboratory, Chilton, Didcot, Oxon OX11 0QX, UK,
}

\begin{abstract}
The structure and vibrational spectroscopy of 2,5-diiodothiophene have been described for the first time. The structure is remarkable in that despite the presence of eight molecules in the unit cell, there is almost no evidence for any interaction between them. This is reflected in the spectra that show coincident modes in the infrared, Raman and inelastic neutron scattering (INS) spectra and almost resolution limited linewidths in the INS spectrum, showing that the both the factor group splitting and the phonon dispersion is very small. This property has led to the use of the compound as a calibrant in INS spectroscopy. The deductions from the spectra are confirmed by a periodic-DFT calculation that allows a complete spectral assignment to be made. Comparison to the INS and Raman spectra of polythiophene (for which 2,5-diiodothiophene may be used as a monomer), shows a marked similarity for the former and a marked difference to the latter. The INS spectrum of polythiophene is dominated by the $\mathrm{C}-\mathrm{H}$ bending modes, which are unchanged on polymerisation. In contrast, the Raman spectrum of polythiophene is dominated by the changed electronic environment which results in strong electron-phonon coupling and a significant upshift of the $\mathrm{C}=\mathrm{C}$ stretch modes.
\end{abstract}




\section{INTRODUCTION}

Polymeric solar cells are a promising alternative for producing clean and renewable energy due to the possibility of fabricating them onto large areas of lightweight, flexible substrates by solution processing at low cost. ${ }^{1}$ In this context, oligothiophenes ${ }^{2}$ and polythiophenes ${ }^{3,4}$ are attracting increasing interest because they offer a range of promising properties. In part, this arises because thiophene chemistry is well-developed ${ }^{5}$ and functionalisation and derivatisation of the $\mathrm{C}_{4} \mathrm{H}_{4} \mathrm{~S}$ core is possible in many different ways.

Alkyl-substituted polythiophenes are soluble and their use as a starting material allows thin film fabrication ${ }^{6}$ using conventional spin-coating methods. Direct deposition of polythiophene solutions into micro- or nanopatterns on various substrates has also been demonstrated by a variety of methods including inkjet printing. ${ }^{7}$ An alternative approach is to polymerise a monomer on a patterned surface. ${ }^{8} 2,5$-Diiodothiophene is a promising material for this method because the $\mathrm{C}-\mathrm{I}$ bonds can be selectively dissociated by ultraviolet irradiation, generating thienyl radicals that polymerise. ${ }^{8-10}$

Vibrational spectroscopy provides a valuable method to characterise the materials and, to this end, the spectra of polythiophene, ${ }^{11-13}$ oligothiophenes ${ }^{14-18}$ and thiophene ${ }^{19-21}$ have been assigned. However, the spectra of 2,5-diiodothiophene have been little investigated, apart from reports of the infrared spectrum ${ }^{9,22}$ and that of its 2,5and $3,4-{ }^{13} \mathrm{C}$ isotopomers. ${ }^{22}$ The assignments were made by comparison to thiophene and polythiophene. The standard method for assigning the spectra, comparison with $a b$ initio calculations, is hampered by the absence of structural information about the molecule. In this work, we present a structural characterisation of 2,5-diiodothiophene by single crystal X-ray diffraction and a complete assignment of the vibrational 
(infrared, Raman and inelastic neutron scattering (INS)) spectra of the molecule, with the assignments supported by periodic density functional theory (DFT) calculations.

\section{EXPERIMENTAL SECTION}

Materials. 2,5-Diiodothiophene was purchased from Aldrich and polythiophene from Rieke Metals and both were used as received.

X-ray Crystallography.. An X-ray diffraction experiment on 2,5-diiodothiophene was carried out at 180(2) K on an Oxford Diffraction XCalibur Gemini diffractometer using Mo-K $\alpha$ radiation $(\lambda=0.71073 \AA)$. Intensities were integrated and absorption corrections were based on equivalent reflections using the CrysAlisPro software. ${ }^{23}$ The structure was solved using olex2.solve ${ }^{24}$ and refined against F2 in SHELXL ${ }^{25,26}$ using OLEX2 ${ }^{27}$. All of the non-hydrogen atoms were refined anisotropically. All of the hydrogen atoms were located geometrically and refined using a riding model. A summary of details of the crystallographic data collection and refinement are given in Table 1.

Crystallographic data for the compound has been deposited with the Cambridge Crystallographic Data Centre as supplementary publication CCDC 1537252. Copies of the data can be obtained free of charge on application to CCDC, 12 Union Road, Cambridge CB2 1EZ, UK [fax(+44) 1223 336033, e-mail: deposit@ccdc.cam.ac.uk] Vibrational Spectroscopy. The INS spectrum was recorded at $20 \mathrm{~K}$ with $\mathrm{TOSCA}^{28}$ at ISIS (Didcot, UK). ${ }^{29}$ The infrared spectrum (500 to $4000 \mathrm{~cm}^{-1}$ at $4 \mathrm{~cm}^{-1}$ resolution) was recorded over the temperature range 113 - 300 K using a Bruker Vertex70 FTIR spectrometer with the sample held in a Specac Low Temperature Golden Gate ATR using 256 scans with a $\mathrm{KBr}$ beamsplitter and a DTGS detector. High resolution $\left(1 \mathrm{~cm}^{-1}\right)$ Raman spectra were recorded at room temperature with a Bruker FT-Raman spectrometer using $1064 \mathrm{~nm}$ excitation, $200 \mathrm{~mW}$ laser power and 1024 scans. Variable 
temperature $(16-300 \mathrm{~K})$ Raman spectra were recorded with a customised ${ }^{30}$ Renishaw InVia system with $785 \mathrm{~nm}$ excitation. Since the initial report, ${ }^{30}$ the system has been upgraded with new laser rejection filters that enable Raman shifts as small as $40 \mathrm{~cm}^{-1}$ to be observed. A second grating with higher dispersion (1800 lines $\mathrm{mm}^{-1}$ vs. 1200 lines $\mathrm{mm}^{-1}$ ) has also been added that provides $\sim 3 \mathrm{~cm}^{-1}$ resolution across the $40-1800 \mathrm{~cm}^{-1}$ region with $785 \mathrm{~nm}$ excitation.

UV-vis Spectroscopy. The UV-vis spectrum was recorded in diffuse reflectance at room temperature using a Shimadzu UV-1800 spectrometer.

Computational Methods. DFT calculations were carried out with the plane-wave pseudopotential method as implemented in CASTEP. ${ }^{31}$ For the initial structure, the crystal structure as determined by X-ray diffraction in this work was used. The lattice parameters were fixed at the experimental values and the molecular geometry was optimised. The generalised gradient approximation (GGA) Perdew-Burke-Ernzerhof (PBE) functional was used in conjunction with optimised norm-conserving pseudopotentials. The plane-wave cut-off energy was $750 \mathrm{eV}$ and a $4 \times 4 \times 8$ (16 k-points) Monkhorst-Pack grid was used. All of the calculations were converged so that the residual forces were less than $|0.005| \mathrm{eV} \AA^{-1}$. After geometry optimisation, the vibrational spectra (INS, infrared and Raman) were calculated in the harmonic approximation using density-functional perturbation-theory. ${ }^{32,33}$ This procedure generates the vibrational eigenvalues and eigenvectors, which allows visualisation of the modes within Materials Studio ${ }^{34}$ and is also the information needed to calculate the INS spectrum using the program ACLIMAX.$^{35}$ Transition energies for isotopic species were calculated from the dynamical matrix that is stored in the CASTEP checkpoint file using the PHONONS utility. ${ }^{36}$ We emphasise that none of the transition energies have been scaled. 


\section{RESULTS AND DISCUSSION}

Solid State Structure. The crystal structure of 2,5-diiodothiophene at $180 \mathrm{~K}$ as determined by single crystal X-ray diffraction is shown in Figure 1. The structure is orthorhombic, $P b c a$ (no. 61), with eight molecules in the primitive cell, which are all on general sites ( $C_{1}$ symmetry). However, as may be seen from Table 2 , that lists selected bond distances and angles, the molecule is almost planar with approximate $C_{2 \mathrm{v}}$ symmetry. The experimental geometry is well-reproduced by the CASTEP calculations; all of the bond distances and angles agree to within $0.1 \AA$ and $1^{\circ}$ respectively. The only exception is for the $\mathrm{C}-\mathrm{H}$ bond distance which, as is usually found, is underestimated in the X-ray determination. A comparison of the complete observed and calculated structures was performed with the Crystal Packing Similarity facility in MERCURY ${ }^{37}$ and the result is shown in Figure S1. Omitting the hydrogens gives an rms difference of 0.032 , showing a very high level of agreement. (Inclusion of the hydrogen atoms results in an rms difference of 0.088 ). The calculations do produce a somewhat more symmetrical molecule.

The molecules within the unit cell are effectively isolated, the closest intermolecular contact is at $3.0 \AA$ and is between $\mathrm{H} 1$ and $\mathrm{H} 2^{\prime}$ on adjacent molecules. This is beyond the sum of the van der Waals radius of hydrogen $(2.4 \AA) .{ }^{38}$ Bifurcated $\mathrm{I} \cdots \mathrm{I}$ contacts of 3.731(1) and 3.837(1) $\AA$ were identified at both ends of the molecule between symmetry related molecules forming chains of $\mathrm{I} \cdots \mathrm{I}$ contacts in the $c$ direction and creating $2 \mathrm{D}$ planes parallel to the $a c$ plane. The distances are within twice van der Waals radius of iodine, $2.04 \AA{ }^{38}$ so this is probably the interaction responsible for the stability of the crystal. There is no evidence for $\pi-\pi$ stacking. 


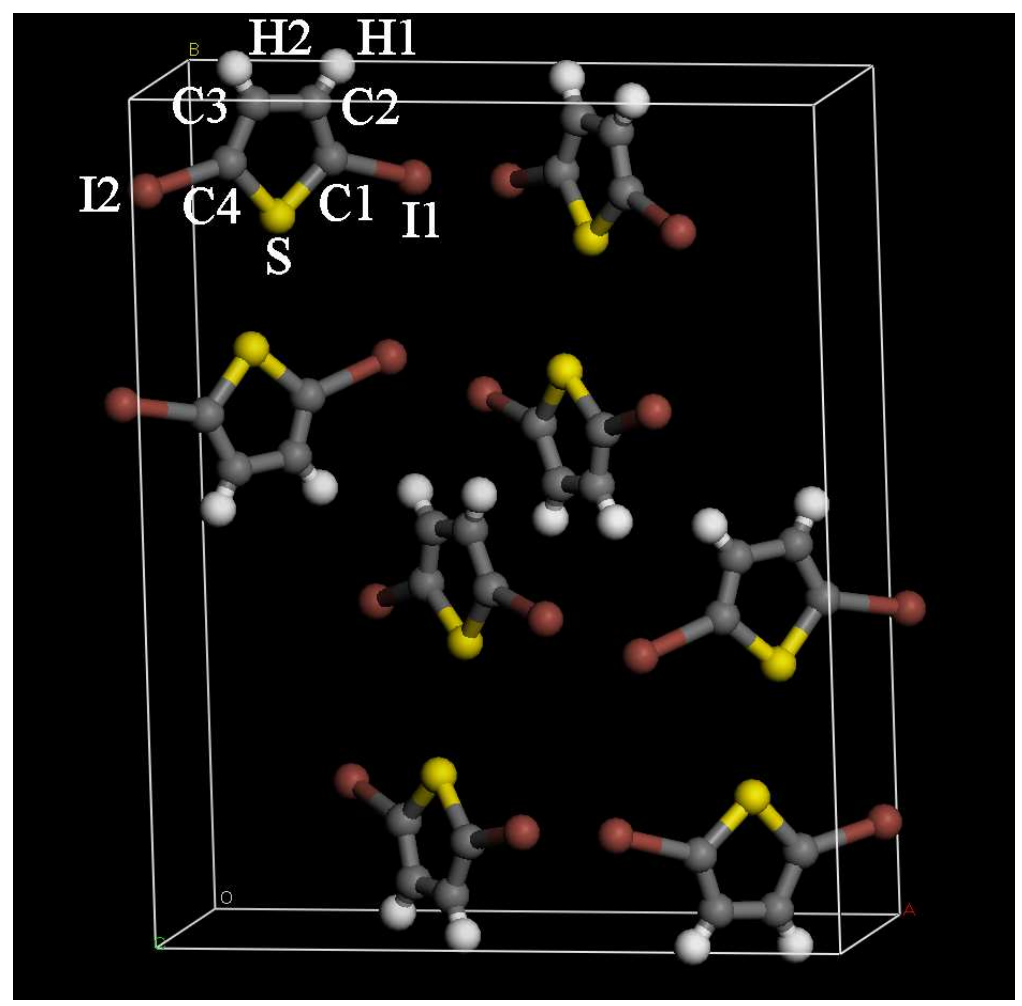

Figure 1: Solid state structure of 2,5-diiodothiophene as determined by single crystal X-ray diffraction at180 K.

Vibrational Spectroscopy. Figure 2 compares the low temperature infrared (113 K), Raman (16 K) and INS (20 K) spectra of 2,5-diiodothiophene. The spectra emphasise the complementarity of, and the need for all three types of spectroscopy in order to observe all of the modes.

It can be seen that there is a remarkable degree of concurrence between all three spectra. Since the space group is centrosymmetric, coincident modes in the infrared and Raman spectra would not be expected. With eight molecules in the unit cell it would be expected that the factor group splitting would result in distinct differences between the spectra as the individual factor group components would have different infrared and Raman intensities while the INS spectrum would be a sum of all the components (since there are no selection rules in INS spectroscopy). The presence of modes at the same 
transition energy in the infrared and Raman spectra demonstrates that the factor group splitting is very small, a few wavenumbers or so.

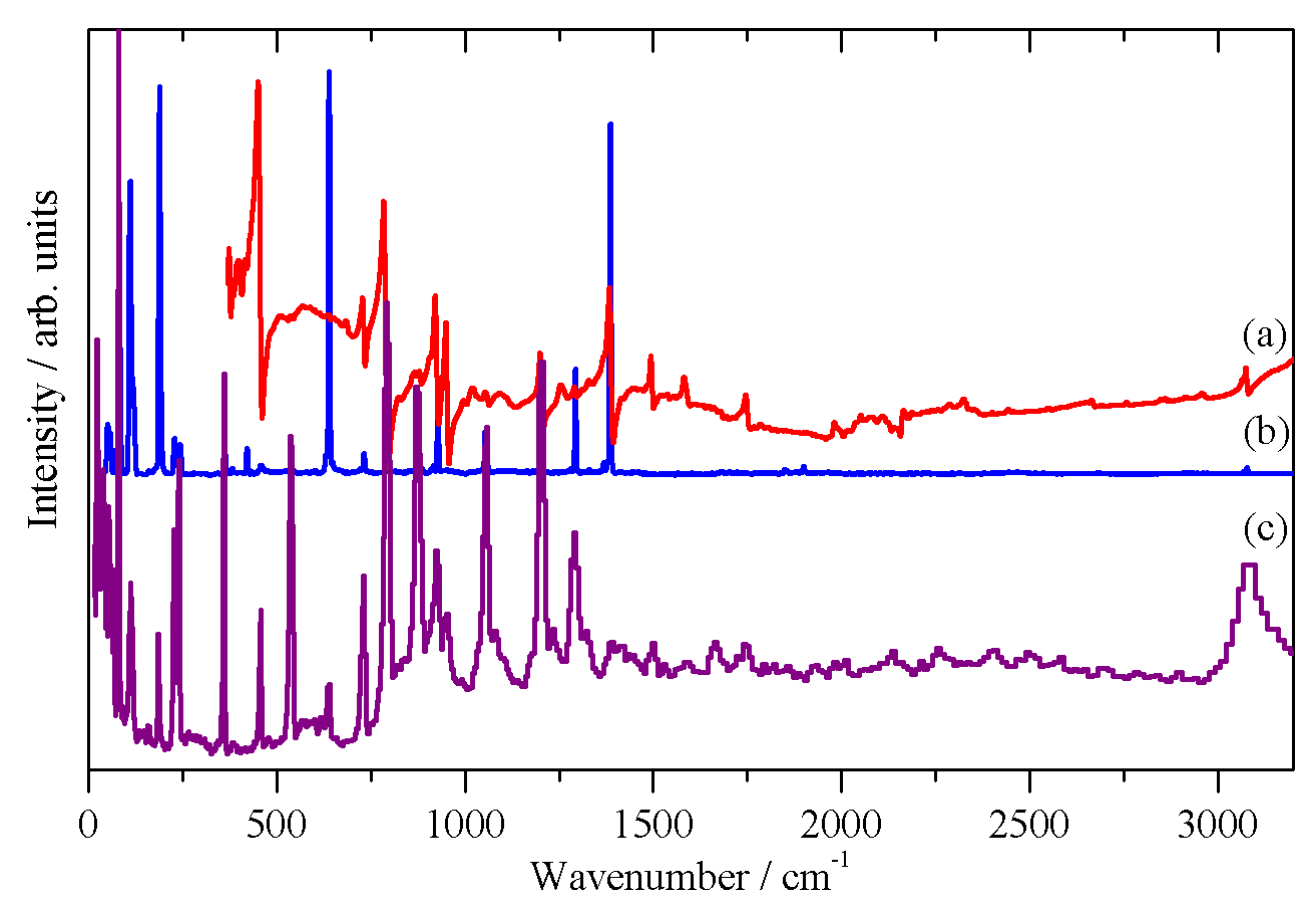

Figure 2: Low temperature vibrational spectra of 2,5-diiodothiophene. (a) Infrared at $113 \mathrm{~K}$, (b) Raman at $20 \mathrm{~K}$ and (c) INS at $20 \mathrm{~K}$.

Figure 3 shows the low energy Raman spectra as a function of temperature in the range $16-300 \mathrm{~K}$, this region is displayed because it is the only one that shows any significant change with temperature. (Extended range Raman spectra $40-1800 \mathrm{~cm}^{-1}$ are shown in Figure S2 and infrared spectra at 111, 180 and $300 \mathrm{~K}$ are shown in Figure S3). Three groups of bands are present: at $40-60 \mathrm{~cm}^{-1}, \sim 80 \mathrm{~cm}^{-1}$ and $100-130 \mathrm{~cm}^{-1}$, on the basis of the periodic-DFT calculations to be described in the next section, these are assigned as: mixed translational and librational modes, librational modes and the $\mathrm{C}-\mathrm{I}$ bending modes (out-of-plane at $100-110 \mathrm{~cm}^{-1}$ and in-plane at $110-130 \mathrm{~cm}^{-1}$ ) respectively. The translational and librational modes harden and sharpen as the temperature is reduced, exactly as would be expected as the lattice contracts. The C-I 
bending modes behave similarly; the major peak at $106 \mathrm{~cm}^{-1}$ shifts slightly to $107.5 \mathrm{~cm}^{-}$ 1 , the pronounced shoulder at $\sim 109 \mathrm{~cm}^{-1}$ shifts to $111.4 \mathrm{~cm}^{-1}$ and becomes a distinct peak. The very weak in-plane $\mathrm{C}-\mathrm{I}$ bending modes, that are only present as a weak shoulder at $300 \mathrm{~K}$, are clearly resolved at $16 \mathrm{~K}$. All of these changes are continuous from room temperature to $16 \mathrm{~K}$, thus we conclude that there are no phase transitions between 300 and $16 \mathrm{~K}$ and that the $180 \mathrm{~K}$ crystal structure is maintained in this temperature range.

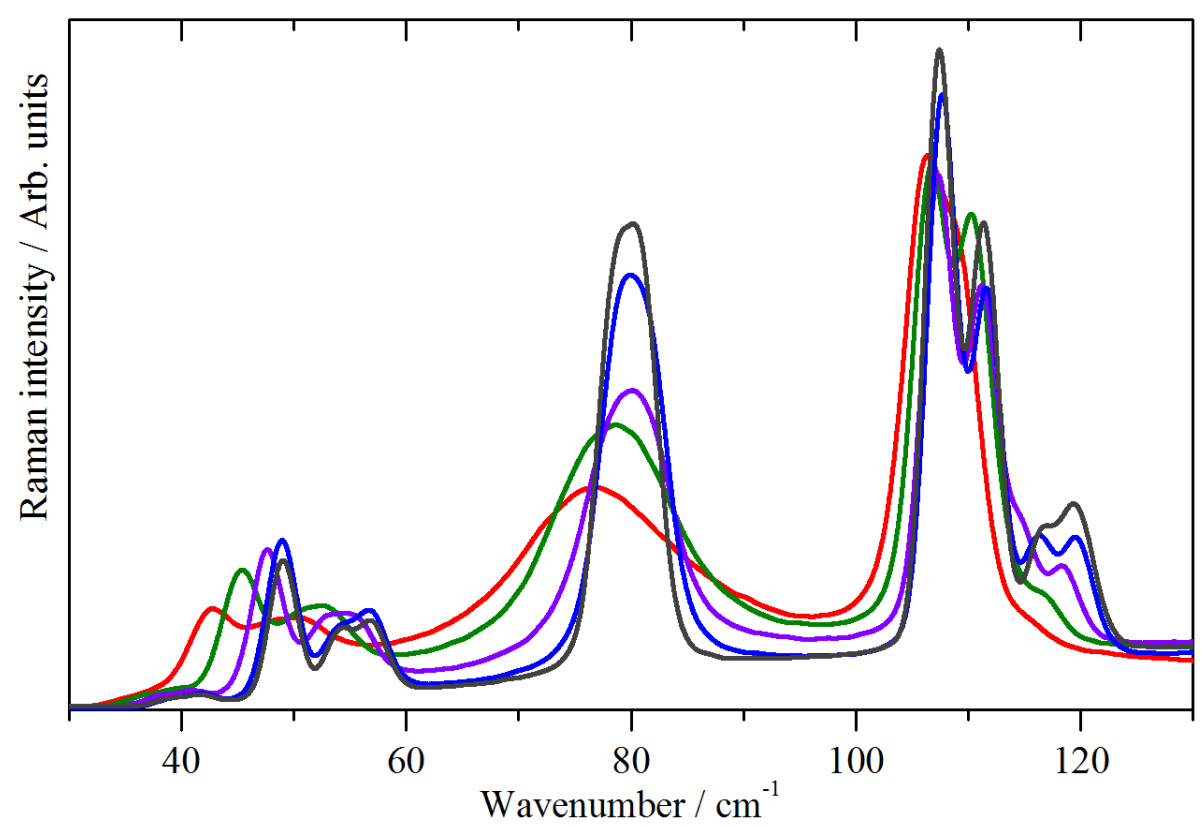

Figure 3: Variable temperature Raman spectra of 2,5-diiodothiophene in the $30-130$ $\mathrm{cm}^{-1}$ region. Red: $300 \mathrm{~K}$, olive $180 \mathrm{~K}$, purple $100 \mathrm{~K}$, blue $50 \mathrm{~K}$ and black $16 \mathrm{~K}$.

A comparison of the observed and calculated INS, infrared and Raman spectra are shown in Figures 4-6. It can be seen that in all cases the agreement is essentially quantitative for both the transition energies and relative intensities. For the infrared spectrum, Figure 5, while the calculation correctly reproduces the positions and intensities of the major peaks, there are also a number of additional peaks. These are due to overtones and combinations which are the result of anharmonicity. This is 
beyond the scope of the work as the phonon calculations assume a harmonic potential. It is somewhat surprising that they are observed with such intensity, these seems to be a feature of the use of the ATR technique. The derivative-like line shape is a result of the Christiansen effect, caused by the particle size. We note that the $785 \mathrm{~nm}$ excitation used for the Raman spectrum is well outside the absorption envelope (see inset in Figure 6), thus resonance or pre-resonance effects are absent and the calculated relative intensities well-match those observed. Table S1 lists the calculated vibrational transition energies at the $\Gamma$-point, their symmetries and the infrared and Raman intensities of 2,5diiodothiophene in the solid state in space group $\mathrm{Pbca}$ with factor group $\mathrm{D}_{2 \mathrm{~h}}$. As previously deduced from the spectra, the calculations show that the factor group splitting is very small; generally only a few wavenumbers.

Table 3 lists the observed bands and their assignments. It can be seen that the modes fall into distinct groups: external modes below $100 \mathrm{~cm}^{-1}$, the $\mathrm{C}-\mathrm{I}$ bend and stretch modes in the range $100-365 \mathrm{~cm}^{-1}$, ring torsions at $450-550 \mathrm{~cm}^{-1}, \mathrm{C}-\mathrm{S}$ stretches at $650-750 \mathrm{~cm}^{-1}$, out-of-plane $\mathrm{C}-\mathrm{H}$ bending modes at $750-900 \mathrm{~cm}^{-1}$, the inplane ring deformations at $900-1000 \mathrm{~cm}^{-1}$, the in-plane $\mathrm{C}-\mathrm{H}$ bending modes at $1050-$ $1200 \mathrm{~cm}^{-1}, \mathrm{C}-\mathrm{C}$ and $\mathrm{C}=\mathrm{C}$ stretches at $1250-1500 \mathrm{~cm}^{-1}$ and the $\mathrm{C}-\mathrm{H}$ stretches at $>3100$ $\mathrm{cm}^{-1}$. 


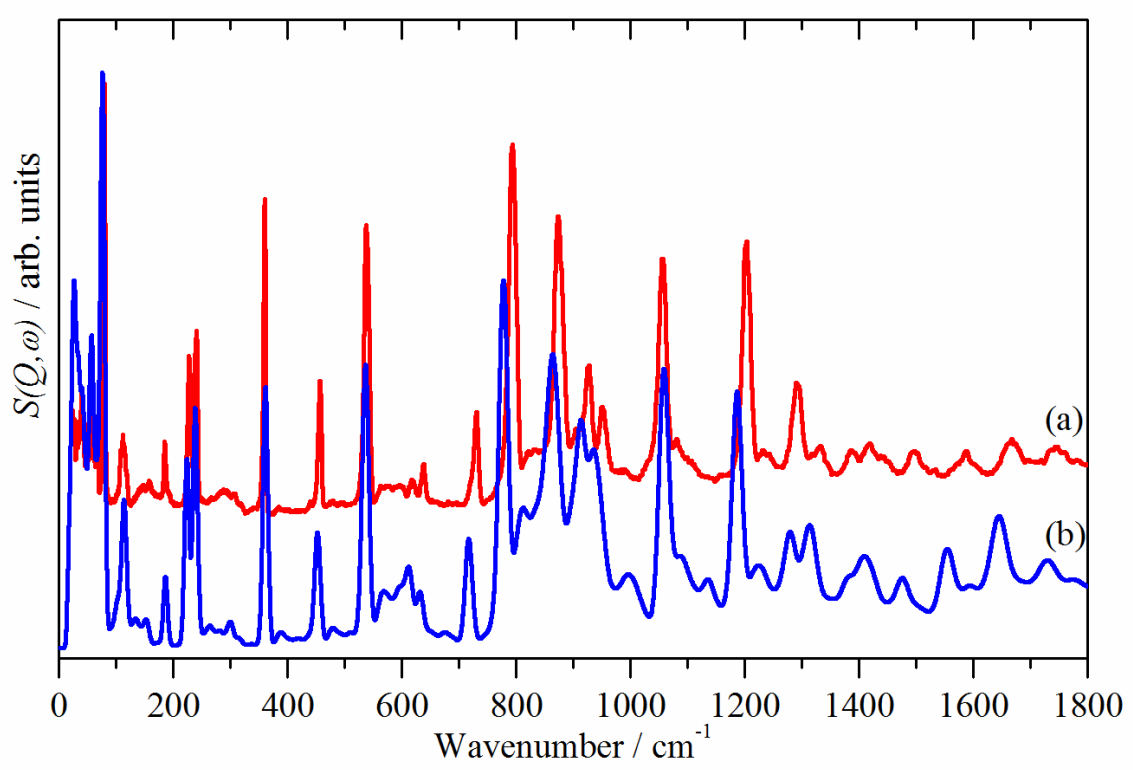

Figure 4: Observed (a) and CASTEP calculated (b) INS spectra of 2,5-diiodothiophene at $20 \mathrm{~K}$.

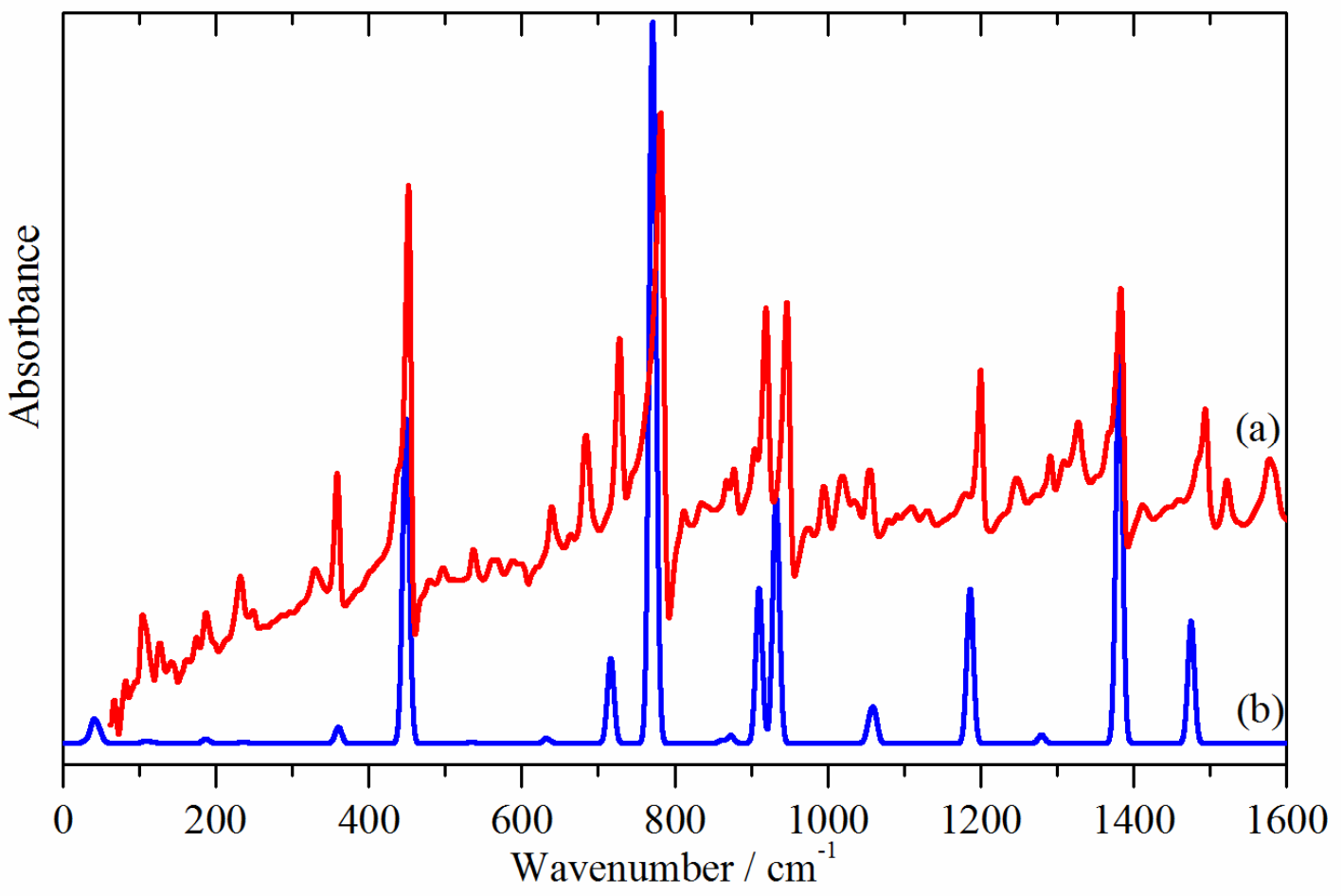

Figure 5: Observed (a) and CASTEP calculated (b) infrared spectra of 2,5diiodothiophene at $300 \mathrm{~K}$. 


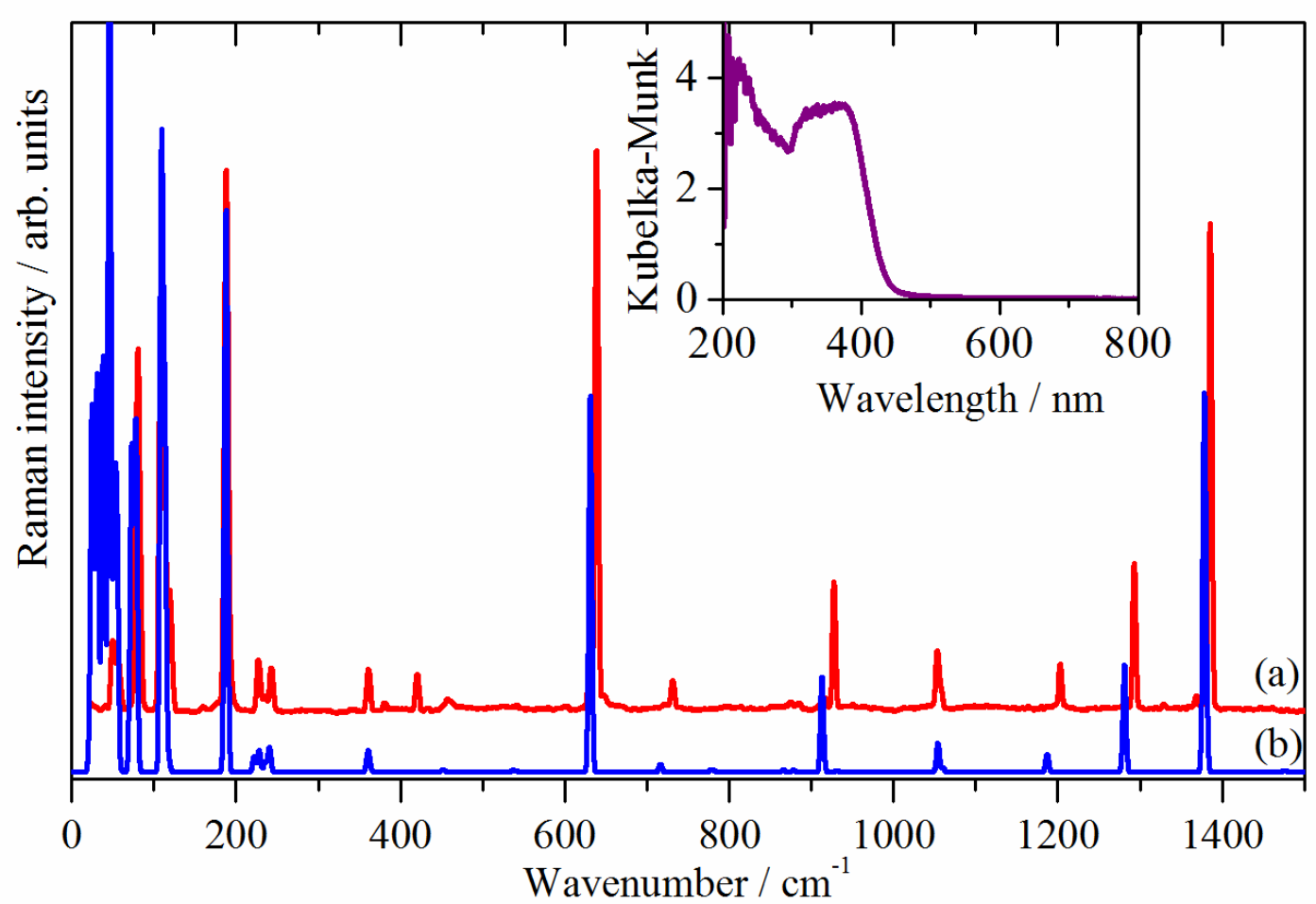

Figure 6: Observed (a) and CASTEP calculated (b) Raman spectra of 2,5-

diiodothiophene at $16 \mathrm{~K}$. The inset shows the diffuse reflectance UV-vis spectrum of the compound at room temperature.

As a further check on the calculation, the infrared spectra of the ${ }^{13} \mathrm{C}$ isotopomers ${ }^{22} 2,5$-diiodo-2,5- ${ }^{13} \mathrm{C}$-thiophene and 2,5 -diiodo-3,4- ${ }^{13} \mathrm{C}$-thiophene were also generated $^{36}$ from the dynamical matrix that is created as part of the CASTEP vibrational analysis. ${ }^{32,33}$ Figure 7 compares observed and calculated spectra for the isotopomers and excellent agreement is obtained. 

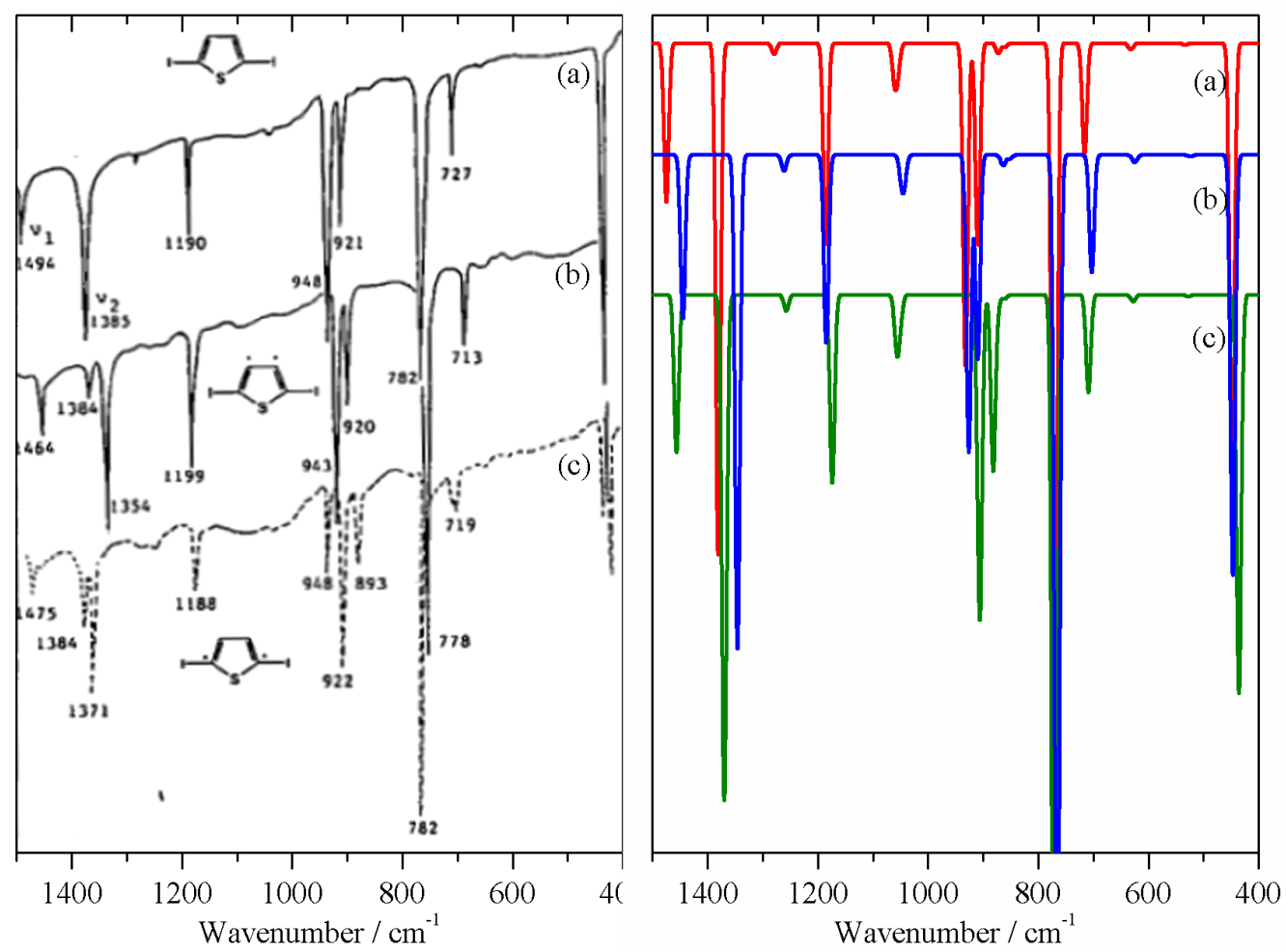

Figure 7: Left: observed ${ }^{22}$ and right: CASTEP calculated infrared spectra of 2,5diiodothiophene isotopomers at $300 \mathrm{~K}$. (a) 2,5-diiodothiophene, (b) 2,5-diiodo-3, $4-{ }^{13} \mathrm{C}$ thiophene and (c) 2,5-diiodo-2,5- ${ }^{13} \mathrm{C}$-thiophene. The left part of the figure is reproduced with permission from John Wiley and Sons, Inc.

Infrared and Raman spectra are measured at the $\Gamma$-point in the Brillouin zone i.e. (almost) zero wavevector. In contrast, INS spectra are measured at all wavevectors and the calculated INS spectrum in Figure 4 is generated from a calculation of the transition energies as a function of wavevector (dispersion) across the entire Brillouin zone.

Figure 8 shows the dispersion plot for 2,5-diiodothiophene. The modes are noticeable for being almost dispersionless: even the optic whole-body (external) modes are almost flat, Figure 8a. This is clearly seen for the $\mathrm{C}-\mathrm{H}$ stretch modes, Figure 8b, and the inplane ring deformation modes, Figure $8 \mathrm{c}$, where the dispersion is less than the factor group splitting. This is the spectral consequence of the absence of any significant 
intermolecular interaction that is apparent from the structural determination. The result is that the INS modes are very sharp and on many instruments are resolution limited, (although not on TOSCA). ${ }^{39}$ This has led to 2,5-diidothiophene becoming the compound of choice for both resolution and wavenumber calibration. ${ }^{23,40,41}$ The low temperature INS, infrared and Raman spectra are available as images and as ASCII files from the INS database (http://wwwisis2.isis.rl.ac.uk/INSdatabase/ ).
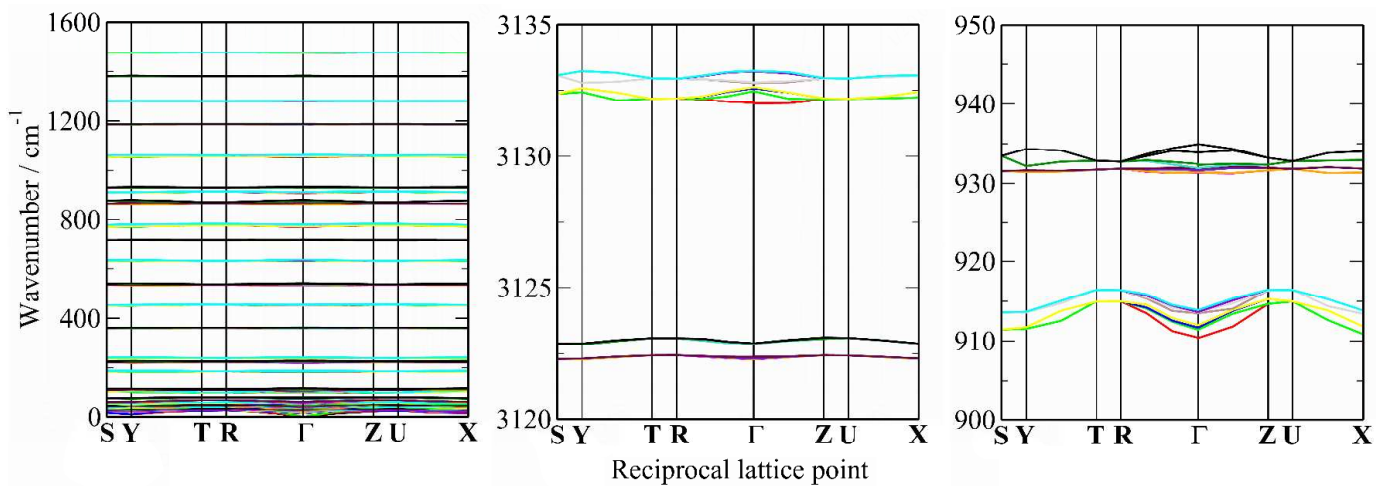

Figure 8: CASTEP calculated dispersion curves of 2,5-diiodothiophene: (a) the fingerprint region, (b) $\mathrm{C}-\mathrm{H}$ stretch region and (c) expanded view of the in-plane ring deformation modes.

Comparison to polythiophene. Figure 9 compares the INS spectra of 2,5-

diiodothiophene and polythiophene. It is seen that there is considerable similarity for the region $>500 \mathrm{~cm}^{-1}$. This is as expected because the lattice modes of the polymer and the molecule will be different character, while the range $100-365 \mathrm{~cm}^{-1}$ region of 2,5diiodothiophene is dominated by the $\mathrm{C}-\mathrm{I}$ bend and stretch modes (Table 3). The strong bands in the $800-1200 \mathrm{~cm}^{-1}$ region are $\mathrm{C}-\mathrm{H}$ bending modes and these are almost unchanged on going from the "monomer" to the polymer. 


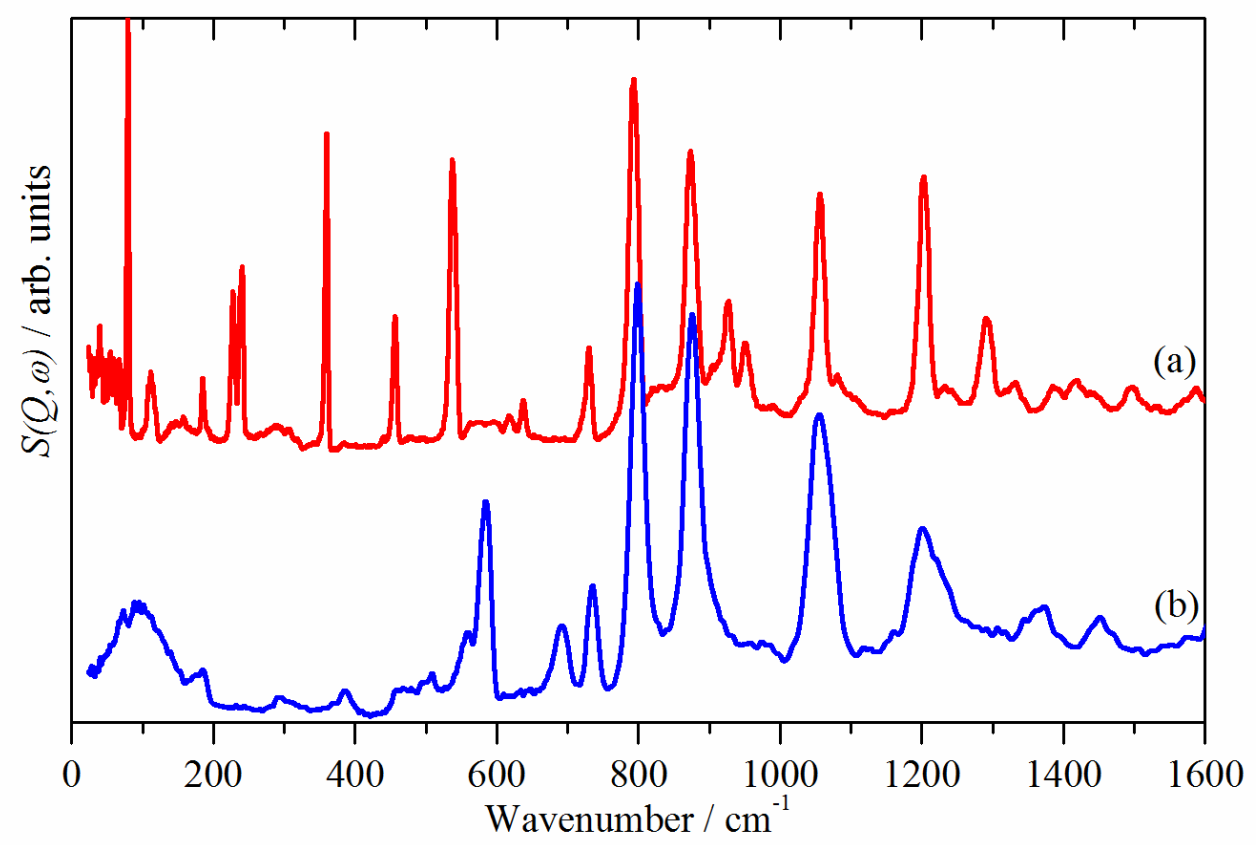

Figure 9: Comparison of the INS spectra of: (a) 2,5-diiodothiophene and (b) polythiophene at $16 \mathrm{~K}$.

The similarity in the INS spectra is in marked contrast to that of the Raman spectra. Figure 10 compares the high resolution $\left(1 \mathrm{~cm}^{-1}\right)$ FT-Raman spectra of the two materials. Except for the $\mathrm{C}-\mathrm{H}$ in-plane bending mode at $\sim 1050 \mathrm{~cm}^{-1}$ there are almost no coincident modes. The $\mathrm{C}=\mathrm{C}$ stretch mode has shifted up to $1456 \mathrm{~cm}^{-1}$ from $1383 \mathrm{~cm}^{-1}$ and has broadened from $4 \mathrm{~cm}^{-1}$ to $14 \mathrm{~cm}^{-1}$ full width at half height, both effects are a result of the sequence length in polythiophene as previously noted. ${ }^{42}$

It is also striking that there are very few modes apparent and that the $\mathrm{C}-\mathrm{H}$ stretch modes are absent in the polythiophene spectrum. This is similar to what is observed in $\beta$-carotene, ${ }^{43,44}$ (which contains an all-trans sequence of alternating $\mathrm{C}=\mathrm{C}$ and $\mathrm{C}-\mathrm{C}$ bonds and is a model compound for polyacetylene), in this case the effect was ascribed to electron-phonon coupling. ${ }^{45}$ 


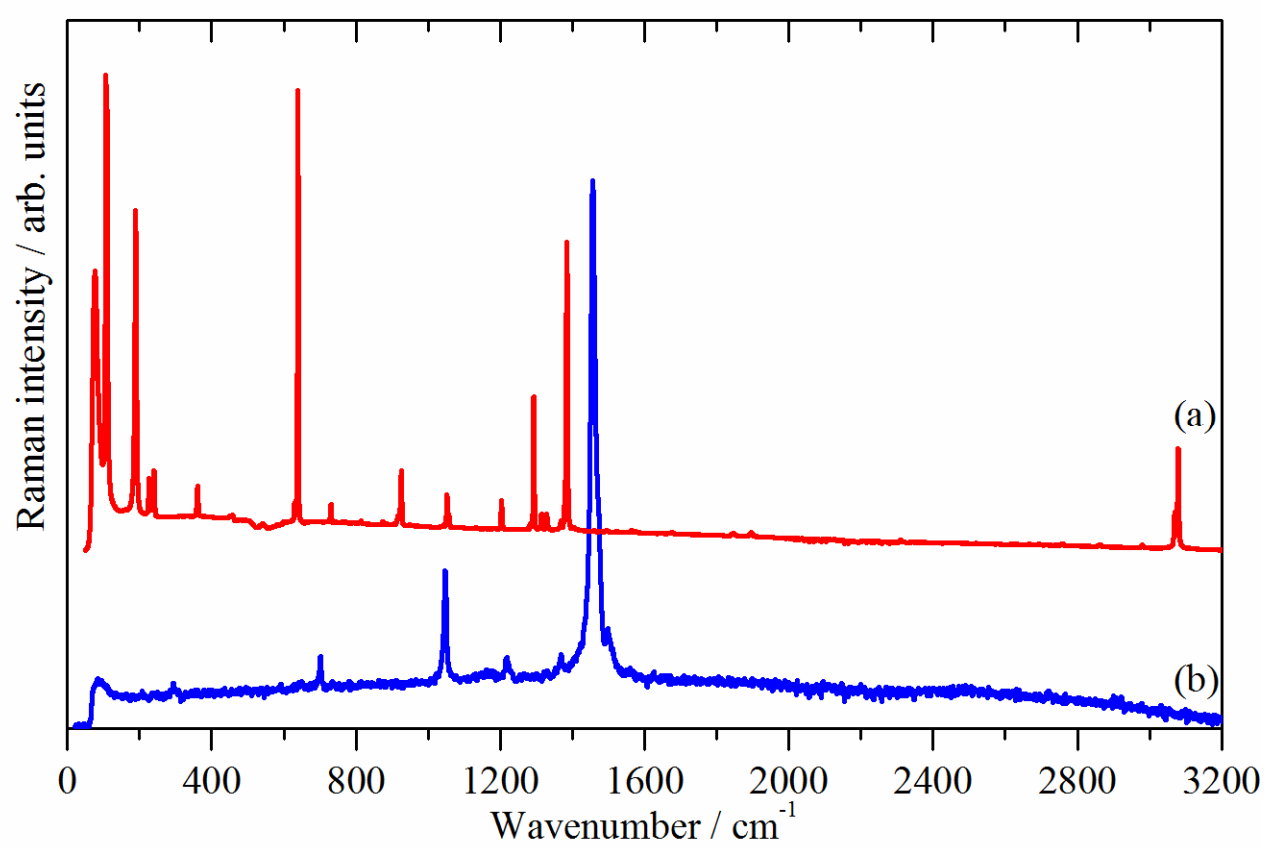

Figure 10: Comparison of the $1 \mathrm{~cm}^{-1}$ resolution FT-Raman spectra of: (a) 2,5-

diiodothiophene and (b) polythiophene at room temperature.

\section{CONCLUSIONS}

The structure and vibrational spectroscopy of 2,5-diiodothiophene have been described for the first time. The structure is remarkable, in that despite the presence of eight molecules in the unit cell, there is almost no evidence for any interaction between them. This is reflected in the spectra that show coincident modes in the infrared, Raman and INS spectra and almost resolution limited linewidths in the INS spectrum, showing that both the factor group splitting and the phonon dispersion are very small. This property has led to the use of the compound as a calibrant in INS spectroscopy.

Comparison to the INS and Raman spectra of polythiophene (for which 2,5diiodothiophene may be used as a monomer), shows that the INS spectrum of polythiophene is dominated by the $\mathrm{C}-\mathrm{H}$ bending modes, which are unchanged on polymerisation. In contrast, the Raman spectrum of polythiophene is dominated by the changed electronic environment which results in strong electron-phonon coupling and a 
significant upshift of the $\mathrm{C}=\mathrm{C}$ stretch modes.

\section{AUTHOR INFORMATION}

Corresponding Author

*E-mail: stewart.parker@stfc.ac.uk

\section{ORCID}

Stewart F. Parker: 0000-0002-3228-2570

Jack L. Parker: 0000-0003-3676-4267

Marek Jura: 0000-0002-4580-6126

\section{Notes}

The authors declare that there are no conflicts of interest.

\section{ASSOCIATED CONTENT}

\section{Supporting Information}

Table of calculated vibrational transition energies at the $\Gamma$-point, Raman and infrared spectra as a function of temperature for the $0-1600 \mathrm{~cm}^{-1}$ range.

\section{ACKNOWLEDGEMENTS}

This project was funded by the Science and Technology Facilities Council (STFC). The STFC Rutherford Appleton Laboratory is thanked for access to neutron beam facilities. Drs Jeff Armstrong and Svemir Rudić of the ISIS Facility are thanked for providing the INS spectrum of 2,5-diiodothiophene. Dr Hazel A. Sparkes of Bristol University is thanked for her assistance with the crystallographic data. Computing resources (time on the SCARF compute cluster for the CASTEP calculations) was provided by STFC's eScience facility. This research has been performed with the use of facilities at the Research Complex at Harwell including the FT-Raman spectrometer and UV-vis spectrometer. The authors would like to thank the Research Complex for access and support to these facilities and equipment. 


\section{REFERENCES}

1. Mazzio, K. A.; Luscombe, C. K. The future of organic photovoltaics. Chem. Soc. Rev. 2015, 44, 78-90.

2. Mishra, A.; Ma, C.-Q.; Bäuerle, P. Functional oligothiophenes: molecular design for multidimensional nanoarchitectures and their applications. Chem. Rev. 2009, 109, 1141-1276.

3. Cheng, Y.-J.; Yang, S.-H.; Hsu, C.-S. Synthesis of conjugated polymers for organic solar cell applications. Chem. Rev. 2009, 109, 5868-5923.

4. Kobayashi, M.; Chen, J. Chung, T.-C. Moraes, F. Heeger A. J. Wudl, F. Synthesis and properties of chemically coupled poly(thiophene). Synth. Met. 1984, 9, 77-86.

5. Gronowitz, S.; Hörnfeldt, A.-B. Thiophenes; Elsevier Academic Press: San Diego, CA, 2004.

6. Holdcroft, S. Patterning $\pi$-conjugated polymers. Adv. Mater. 2001, 13, 17531765.

7. Sirringhaus, H.; Kawase, T.; Friend, R. H.; Shimode, T.; Inbasekaran, M.; Wu, W.; Woo, E. P. High-resolution inkjet printing of all-polymer transistor circuits. Science 2000, 290, 2123-2126.

8. Natarajan, S.; Kim, S. H. Maskless fabrication of polythiophene patterns by photochemical conversion of regioselectively condensed 2,5-diiodothiophene. Langmuir 2005, 21, 7052-7056.

9. Liu, G.; Natarajan, S.; Kim, S. H. Photochemical production of oligothiophene and polythiophene micropatterns from 2,5-diiodothiophene on Au in UHV. Surf. Sci. 2005, 592, L305-L309.

10. Liu, G.; Ryoo, K.; Kim, S. H. Thermal reaction and desorption behaviors of 2,5diiodothiophene on clean and passivated Au surfaces. Surf. Sci. 2007, 601, 2967-2972.

11. Furukawa, Y.; Akimoto, M.; Harada, I. Vibrational key bands and electrical conductivity of polythiophene. Synth. Met. 1987, 18, 151-156.

12. Yong. C.; Renyan Q. IR and Raman studies of polythiophene prepared by electrochemical polymerization. Solid State Commun. 1985, 54, 211-213.

13. Agosti, E.; Rivola, M.; Hernandez, V.; Del Zoppo, M., Zerbi, G. Electronic and dynamical effects from the unusual features of the Raman spectra of oligo and polythiophenes. Synth. Met. 1999, 100, 101-112. 
14. Esposti, A.; Moze, O.; Taliani, C.; Tomkinson, J.; Zamboni, R.; Zerbetto, F. The intramolecular vibrations of prototypical polythiophenes. J. Chem. Phys. 1996, 104, 9704-9718.

15. Esposti, A. D.; Zerbetto, F. A density functional study of the vibrations of three oligomers of thiophenes. J. Phys. Chem. A 1997, 101, 7283-7291.

16. van Eijck, L.; Johnson, M. R.; Kearley, G. J. Intermolecular interactions in bithiophene as a model for polythiophene. J. Phys. Chem. A 2003, 107, 89808984.

17. Hermet, P.; Bantignies, J.-L.; Rahmani, A.; Sauvajol, J.-L.; Johnson, M. R. Density-of-states of crystalline 2,2'-bithiophene: ab initio analysis and comparison with inelastic neutron scattering response. J. Phys.: Condens. Matter 2004, 16, 7385-7396.

18. Hermet, P.; Bantignies, J.-L.; Rahmani, A.; Sauvajol, J.-L.; Johnson, M. R. Polymorphism of crystalline $\alpha$-quaterthiophene and $\alpha$-sexithiophene: ab initio analysis and comparison with inelastic neutron scattering response. J. Phys. Chem. A 2005, 109, 4202-4207.

19. Rico, M; Orza, J. M.; Morcillo, J. Fundamental vibrations of thiophene and its deuterated derivatives. Spec. Acta A 1994, 50, 765-795.

20. Klots, T. D.; Chirico, R. D.; Steele, W. V. Complete vapor-phase assignment for the fundamental vibrations of furan, pyrrole and thiophene. Spec. Acta 1965, 21, 689-719.

21. Atter, G. D.; Chapman, D. M.; Hester, R. E.; Green, D. A.; Mitchell P. C. H.; Tomkinson, J. Refined ab initio inelastic neutron scattering spectrum of thiophene. J. Chem. Soc. Faraday Trans. 1997, 93, 2977-2980.

22. Yamamoto, T.; Kamijoh, T.; Wataru, I. Preparation and spectroscopic data of ${ }^{13} \mathrm{C}$-labeled polythiophenes and corresponding iodide monomers. J. Polym. Sci. A Polym. Chem. 2000, 38, 1642-1646.

23. Agilent-Technologies, CrysAlisPro Version 1.171.37.33c, 2000.

24. Bourhis, L. J.; Dolomanov, O. V.; Gildea, R. J.; Howard, J. A. K.; Puschmann, $\mathrm{H}$. The anatomy of a comprehensive constrained, restrained refinement program for the modern computing environment - Olex2 dissected. Acta Cryst. A 2015, 71, 59-75.

25. Sheldrick, G. M. Acta Cryst. A A short history of SHELX. 2008, 64, 112-122. 
26. Sheldrick, G. M. Acta Cryst. C Crystal structure refinement with SHELXL. 2015, 71, 3-8.

27. Dolomanov, O. V.; Bourhis, L. J.; Gildea, R. J.; Howard, J. A. K.; Puschmann, H. OLEX2: a complete structure solution, refinement and analysis program. $J$. Appl. Crystallogr. 2009, 42, 339-341

28. Parker, S.F.; Fernandez-Alonso, F.; Ramirez-Cuesta, A. J.; Tomkinson, J.; Rudić, S.; Pinna, R.S.; Gorini, G.; Fernández Castañon, J. Recent and Future Developments on TOSCA at ISIS. J. Phys. Conf. Ser. 2014, 554, 012003.

29. The ISIS Facility. http://www.isis.stfc.ac.uk/ (accessed May 24, 2017).

30. Adams, M. A.; Parker, S. F.; Fernandez-Alonso, F.; Cutler, D. J.; Hodges, C.; King, A. Simultaneous neutron scattering and Raman scattering. Appl. Spec. 2009, 63, 727-732.

31. Clark, S. J.; Segall, M. D.; Pickard, C. J.; Hasnip, P. J.; Probert, M. J.; Refson, K.; Payne, M.C. First principles methods using CASTEP. Z. Kristallographie 2005, 220, 567-570.

32. Refson, K.; Clark, S. J.; Tulip, P. R. Variational density-functional perturbation theory for dielectrics and lattice dynamics. Phys. Rev. B 2006, 73, 155114.

33. Milman, V.; Perlov, A.; Refson, K.; Clark, S. J.; Gavartin, J.; Winkler, B. Structural, electronic and vibrational properties of tetragonal zirconia under pressure: a density functional theory study. J. Phys.: Condens. Matter 2009, 21, 485404.

34. Dassault Systèmes BIOVIA. http://accelrys.com/products/materials-studio (accessed May 24, 2017).

35. Ramirez-Cuesta, A. J. aCLIMAX 4.0.1, The new version of the software for analyzing and interpreting INS spectra. Comp. Phys. Comm. 2004, 157, 226238.

36. CASTEP. Refson, K. Phonons and related calculations in CASTEP. http://www.castep.org/ (accessed May 24, 2017).

37. The Cambridge Crystallographic Data Centre (CCDC). https://www.ccdc.cam.ac.uk/solutions/csd-system/components/mercury/ (accessed May 24, 2017).

38. Alvarez S. A cartography of the van der Waals territories. Dalton Trans. 2013, 42, 8617- 8636. 
39. Bowden, Z. A.; Celli, M.; Cilloco, F.; Colognesi, D.; Newport, R. J.; Parker, S. F.; Ricci, F. P.; Rossi-Albertini, V.; Sacchetti, F.; Tomkinson, J.; Zoppi, M. The TOSCA incoherent inelastic neutron spectrometer: progress and results. Physica B 2000, 276-278, 98-99.

40. Rossi Albertini, V.; Colognesi, D.; Tomkinson, J. A study on the calibration of a time-focused inelastic neutron scattering spectrometer, J. Neutron Research 2000, $8,245-259$.

41. Ivanov, A.; Jiménez-Ruiz, M.; Kulda, J. IN1-LAGRANGE - the new ILL instrument to explore vibration dynamics of complex materials. J. Phys. Conf. Ser. 2014, 554, 012001.

42. Sauvajol, J. L.; Poussigue, G.; Benoit, C. Sample dependence of Raman spectrum on polythiophene films. Synth. Met. 1991, 41-43, 1237-1242.

43. Harada, I.; Furukawa, Y.; Tasumi, M.; Shirakawa, H.; Ikeda, S. Spectroscopic studies on doped polyacetylene and $\beta$-carotene. J. Chem. Phys. 1980, 73, 47464757.

44. Parker, S. F.; Tavender, S.M.; Dixon, N.M.; Herman, H.; Williams, K. P. J.; Maddams, W. F. The Raman spectrum of $\beta$-carotene using laser lines from green $(514.5 \mathrm{~nm})$ to near-infrared $(1064 \mathrm{~nm})$ : implications for quantitative analysis of polyenes. Applied Spectroscopy 1999, 53. 86-91.

45. Castiglioni, C.; Del Zoppo, M.; Zerbi, G. Vibrational Raman spectroscopy of polyconjugated organic oligomers and polymers. J. Raman Spectrosc. 1993, 24, 485-494. 
Table 1. Crystal data and structure refinement details for 2,5-diiodothiophene.

\begin{tabular}{|c|c|}
\hline Empirical formula & $\mathrm{C}_{4} \mathrm{H}_{2} \mathrm{I}_{2} \mathrm{~S}$ \\
\hline Formula weight & 335.92 \\
\hline Temperature / K & $180(2)$ \\
\hline Crystal system & Orthorhombic \\
\hline Space group & $\mathrm{Pbca}$ \\
\hline Space group number & 61 \\
\hline $\mathrm{a} / \AA$ & $14.9443(9)$ \\
\hline $\mathrm{b} / \AA$ & $18.2941(15)$ \\
\hline $\mathrm{c} / \AA$ & $5.2541(3)$ \\
\hline$\alpha /{ }^{\circ}$ & 90 \\
\hline$\beta / \circ$ & 90 \\
\hline$\gamma / \circ$ & 90 \\
\hline Volume / $\AA^{3}$ & $1436.43(17)$ \\
\hline$Z$ & 8 \\
\hline pcalc $/ \mathrm{g} \mathrm{cm}^{-3}$ & 3.107 \\
\hline$\mu / \mathrm{mm}^{-1}$ & 8.933 \\
\hline $\mathrm{F}(000)$ & 1184.0 \\
\hline Crystal size $/ \mathrm{mm}^{3}$ & $0.1 \times 0.06 \times 0.02$ \\
\hline Radiation & $\operatorname{MoK} \alpha(\lambda=0.71073)$ \\
\hline $2 \theta$ range for data collection $/{ }^{\circ}$ & 5.89 to 52.744 \\
\hline Index ranges & $\begin{array}{r}-18 \leq \mathrm{h} \leq 18 \\
-22 \leq \mathrm{k} \leq 21, \\
-6 \leq 1 \leq 6\end{array}$ \\
\hline Reflections collected & 7641 \\
\hline Rint / Rsigma & $0.0731 / 0.0499$ \\
\hline Data / restraints / parameters & $1466 / 0$ / 64 \\
\hline Goodness-of-fit on F2 & 1.123 \\
\hline Final $R$ indexes $[\mathrm{I}>=2 \sigma(\mathrm{I})]$ & $\begin{array}{r}\mathrm{R} 1=0.0647, \\
\mathrm{wR} 2=0.1754\end{array}$ \\
\hline Final $\mathrm{R}$ indexes [all data] & $\begin{array}{r}\mathrm{R} 1=0.0741, \\
\mathrm{wR} 2=0.1824\end{array}$ \\
\hline Largest diff. peak / hole / e $\AA^{-3}$ & $2.81 /-1.45$ \\
\hline
\end{tabular}


Table 2. Comparison of selected observed and calculated bond distances and angles in 2,5-diiodothiophene.

\begin{tabular}{lcc}
\hline & Observed & Calculated \\
\hline Bond distance / $\AA$ & & \\
S-C1 & 1.699 & 1.727 \\
S-C4 & 1.738 & 1.727 \\
C1-C2 & 1.314 & 1.378 \\
C2-C3 & 1.434 & 1.422 \\
C3-C4 & 1.359 & 1.378 \\
C1-I1 & 2.102 & 2.064 \\
C4-I2 & 2.049 & 2.066 \\
C2-H1 & 0.931 & 1.088 \\
C3-H2 & 0.931 & 1.088 \\
Bond angle / & & \\
S-C1-C2 & 113.6 & 112.0 \\
C1-C2-C3 & 113.1 & 112.4 \\
C2-C3-C4 & 111.2 & 112.3 \\
C3-C4-S & 111.5 & 112.0 \\
C4-S-C1 & 90.5 & 91.3 \\
S-C1-I1 & 120.9 & 121.9 \\
S-C4-I2 & 120.4 & 120.9 \\
Dihedral angle / & & \\
S-C1-C2-C3 & -0.9 & -0.4 \\
C1-C2-C3-C4 & -0.2 & 0.4 \\
C2-C3-C4-S & 0.5 & -0.3 \\
C3-C4-S-C1 & 0.8 & 0.0 \\
C2-C1-I1-S & 1.5 & 1.1 \\
C3-C4-I2-S & 0.6 & 1.3 \\
\hline
\end{tabular}


Table 3. Observed and calculated transition energies of 2,5-diiodothiophene in the solid state.

\begin{tabular}{|c|c|c|c|c|}
\hline $\mathrm{INS} / \mathrm{cm}^{-1}$ & Raman $/ \mathrm{cm}^{-1}$ & ${ }_{1}^{\text {Infrared }} * / \mathrm{cm}^{-}$ & CASTEP $\uparrow / \mathrm{cm}^{-1}$ & Description \\
\hline & & & $\begin{array}{l}19 \\
28\end{array}$ & $\begin{array}{l}\text { Acoustic }+ \text { optic translation } \\
\text { Libration }\end{array}$ \\
\hline $40 w+$ & & & 38 & Translation \\
\hline $55 w$ & $50 \mathrm{w}$ & & 46 & Libration \\
\hline $60 w$ & $56 w$ & & 53 & Translation \\
\hline $80 \mathrm{~s}$ & $80 \mathrm{~s}$ & & 66 & Libration \\
\hline \multirow[t]{2}{*}{$112 \mathrm{w}, \mathrm{br}$} & $110 \mathrm{~s}$ & $104 w$ & 108 & C-I in-phase out-of-plane bend \\
\hline & $119 \mathrm{~m}$ & & 115 & $\mathrm{C}-\mathrm{I}$ in-phase in-plane bend \\
\hline $185 \mathrm{w}$ & $187 \mathrm{~s}$ & $187 \mathrm{w}$ & 187 & $\mathrm{C}-\mathrm{I}$ symmetric stretch \\
\hline $228 \mathrm{~m}$ & $227 \mathrm{w}$ & $232 \mathrm{w}$ & 224 & C-I out-of-phase out-of-plane bend \\
\hline $240 \mathrm{~m}$ & $243 w$ & & 238 & C-I out-of-phase in-plane bend \\
\hline $360 s$ & $361 \mathrm{w}$ & $358 \mathrm{~m}$ & 361 & $\mathrm{C}-\mathrm{I}$ antisymmetric stretch \\
\hline $457 \mathrm{~m}$ & $458 w$ & $456 \mathrm{~s}$ & 451 & Out-of-plane ring deformation ( $\mathrm{C}-\mathrm{S}$ torsion) \\
\hline $538 \mathrm{~s}$ & & & 537 & $\mathrm{C} 2-\mathrm{C} 3$ torsion \\
\hline
\end{tabular}




\begin{tabular}{|c|c|c|c|c|}
\hline $638 w$ & $639 \mathrm{~s}$ & & 632 & $\mathrm{C} 1-\mathrm{S}+\mathrm{C} 4-\mathrm{S}$ in-phase stretch \\
\hline $730 \mathrm{~m}$ & $731 \mathrm{w}$ & $731 \mathrm{w}$ & 717 & $\mathrm{C} 1-\mathrm{S}+\mathrm{C} 4-\mathrm{S}$ out-of-phase stretch \\
\hline $793 \mathrm{~s}$ & & $789 \mathrm{~s}$ & 776 & In-phase $\mathrm{C}-\mathrm{H}$ out-of-plane bend \\
\hline $874 \mathrm{~s}$ & & & 870 & Out-of-phase C-H out-of-plane bend \\
\hline $926 \mathrm{~m}$ & $917 \mathrm{vw}$ & $924 \mathrm{~m}$ & 913 & $\begin{array}{l}\text { Symmetric in-plane ring deformation } \\
\text { (in-phase } \mathrm{C} 1=\mathrm{C} 2-\mathrm{C} 3+\mathrm{C} 4=\mathrm{C} 3-\mathrm{C} 2 \text { bend) }\end{array}$ \\
\hline $950 \mathrm{~m}$ & $927 w$ & $948 \mathrm{~m}$ & 932 & $\begin{array}{l}\text { Antisymmetric in-plane ring deformation } \\
\text { (out-of-phase } \mathrm{C} 1=\mathrm{C} 2-\mathrm{C} 3+\mathrm{C} 4=\mathrm{C} 3-\mathrm{C} 2 \text { bend) }\end{array}$ \\
\hline $1057 \mathrm{~m}$ & $1053 \mathrm{w} / 1058 \mathrm{sh}$ & & 1058 & $\mathrm{C}-\mathrm{H}$ in-plane symmetric bend \\
\hline $1203 \mathrm{~m}$ & $1203 w$ & & 1187 & $\mathrm{C}-\mathrm{H}$ in-plane antisymmetric bend \\
\hline \multirow[t]{5}{*}{$1291 \mathrm{~m}$} & $1293 \mathrm{~m}$ & & 1280 & $(\mathrm{C} 1=\mathrm{C} 2+\mathrm{C} 3=\mathrm{C} 4$ in-phase stretch $)+(\mathrm{C} 2-\mathrm{C} 3$ stretch $)$ \\
\hline & \multirow[t]{2}{*}{$1385 \mathrm{~s}$} & $1387 \mathrm{~s}$ & 1380 & $\mathrm{C} 2-\mathrm{C} 3$ stretch $+(\mathrm{C} 1=\mathrm{C} 2+\mathrm{C} 3=\mathrm{C} 4$ in-phase stretch $)$ \\
\hline & & $1497 \mathrm{~m}$ & 1475 & $\mathrm{C} 1=\mathrm{C} 2+\mathrm{C} 3=\mathrm{C} 4$ out-of-phase stretch \\
\hline & $3067 w$ & $3068 \mathrm{w}, \mathrm{sh}$ & 3123 & Out-of-phase C-H stretch \\
\hline & $3078 w$ & $3077 \mathrm{w}$ & 3133 & In-phase $\mathrm{C}-\mathrm{H}$ stretch \\
\hline
\end{tabular}

$\dagger$ Values $<400 \mathrm{~cm}^{-1}$ are taken from the $300 \mathrm{~K}$ data (Figure S3a), those at $>400 \mathrm{~cm}^{-1}$ from the $111 \mathrm{~K}$ data (Figures 5a and S3c).

*Calculated values are the average of the factor group split octet at the $\Gamma$-point from the solid state calculation, the complete list is given in Table S1.

$+\mathrm{w}=$ weak, $\mathrm{m}=$ medium, $\mathrm{s}-=$ strong, $\mathrm{sh}=$ shoulder, $\mathrm{v}=$ very, $\mathrm{br}=$ broad. 
Table of Contents graphic.

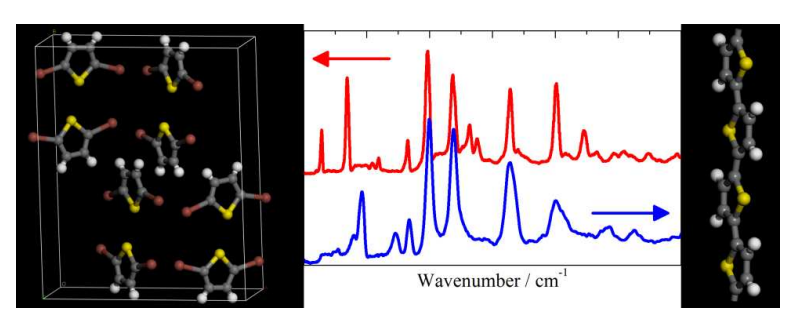


Supplementary Information for:

Structure and Vibrational Spectra of 2,5-Diiodothiophene: a Model for Polythiophene.

Stewart F. Parker,* Jack L. Parker and Marek Jura

ISIS Facility, STFC Rutherford Appleton Laboratory, Chilton, Didcot, Oxon OX11 0QX, UK,

e-mail: stewart.parker@stfc.ac.uk 
Table S1. Complete list of calculated vibrational transition energies at the $\Gamma$-point, symmetries, infrared and Raman intensities of 2,5-diiodothiophene in the solid state in space group $P b c a$ with factor group $D_{2 h}$.

\begin{tabular}{|c|c|c|c|c|}
\hline $\begin{array}{l}\text { Transition } \\
\text { energy } \\
/ \mathrm{cm}^{-1}\end{array}$ & Symmetry & $\begin{array}{c}\text { Infrared } \\
\text { intensity } \\
/ \mathrm{km} \mathrm{mol}^{-1}\end{array}$ & $\begin{array}{c}\text { Raman } \\
\text { intensity } \\
/ \AA^{4} \mathrm{amu}^{-1}\end{array}$ & Description $\dagger$ \\
\hline 0 & $B_{2 u}$ & 0.00 & 0.00 & Acoustic mode \\
\hline 0 & $B_{1 \mathrm{u}}$ & 0.00 & 0.00 & Acoustic mode \\
\hline 0 & $B_{3 u}$ & 0.00 & 0.00 & Acoustic mode \\
\hline 14 & $B_{2 \mathrm{~g}}$ & 0.00 & 0.00 & Translation \\
\hline 16 & $A_{\mathrm{g}}$ & 0.00 & 0.00 & Translation \\
\hline 18 & $B_{2 u}$ & 0.08 & 0.00 & Translation \\
\hline 23 & $A_{\mathrm{u}}$ & 0.00 & 0.00 & Translation \\
\hline 23 & $B_{1 \mathrm{~g}}$ & 0.00 & 2.59 & Translation \\
\hline 25 & $B_{1 \mathrm{u}}$ & 0.00 & 0.00 & Libration \\
\hline 25 & $B_{3 g}$ & 0.00 & 11.60 & Translation \\
\hline 26 & $B_{3 g}$ & 0.00 & 1.93 & Translation \\
\hline 29 & $A_{\mathrm{u}}$ & 0.00 & 0.00 & Libration \\
\hline 29 & $B_{3 \mathrm{u}}$ & 2.01 & 0.00 & Libration \\
\hline
\end{tabular}




$\begin{array}{lllll}31 & B_{2 \mathrm{~g}} & 0.00 & 5.05 & \text { Libration } \\ 31 & B_{1 \mathrm{u}} & 0.15 & 0.00 & \text { Libration } \\ 31 & A_{\mathrm{g}} & 0.00 & 20.67 & \text { Libration } \\ 33 & A_{\mathrm{u}} & 0.00 & 0.00 & \text { Translation } \\ 35 & B_{3 \mathrm{u}} & 0.80 & 0.00 & \text { Translation } \\ 36 & B_{3 \mathrm{~g}} & 0.00 & 0.00 & \text { Translation } \\ 39 & B_{2 \mathrm{~g}} & 0.00 & 36.53 & \text { Translation } \\ 39 & B_{1 \mathrm{~g}} & 0.00 & 0.00 & \text { Translation } \\ 40 & B_{3 \mathrm{u}} & 21.44 & 0.00 & \text { Libration } \\ 41 & A_{\mathrm{g}} & 0.00 & 5.62 & \text { Translation } \\ 43 & B_{2 \mathrm{u}} & 0.05 & 0.00 & \text { Libration } \\ 44 & B_{2 \mathrm{u}} & 0.14 & 0.00 & \text { Translation } \\ 45 & B_{3 \mathrm{u}} & 0.50 & 0.00 & \text { Libration } \\ 45 & B_{1 \mathrm{u}} & 3.14 & 0.00 & \text { Libration } \\ 46 & B_{1 \mathrm{~g}} & 0.00 & 2.33 & \text { Libration } \\ & A_{\mathrm{g}} & 0.00 & 101.80 & \text { Libration }\end{array}$




$\begin{array}{lllll}47 & B_{2 \mathrm{~g}} & 0.00 & 6.09 & \text { Translation } \\ 47 & A_{\mathrm{u}} & 0.00 & 0.00 & \text { Libration } \\ 48 & B_{1 \mathrm{~g}} & 0.00 & 0.00 & \text { Translation } \\ 48 & B_{1 \mathrm{u}} & 8.66 & 0.00 & \text { Libration } \\ 50 & B_{3 \mathrm{~g}} & 0.00 & 0.00 & \text { Libration } \\ 52 & B_{2 \mathrm{u}} & 0.00 & 0.00 & \text { Libration } \\ 52 & B_{2 \mathrm{~g}} & 0.00 & 37.30 & \text { Translation } \\ 53 & B_{1 \mathrm{~g}} & 0.00 & 0.00 & \text { Translation } \\ 55 & B_{3 \mathrm{~g}} & 0.00 & 4.02 & \text { Translation } \\ 55 & A_{\mathrm{g}} & 0.00 & 36.22 & \text { Translation } \\ 56 & B_{3 \mathrm{u}} & 0.26 & 0.00 & \text { Libration } \\ 57 & A_{\mathrm{u}} & 0.00 & 0.00 & \text { Libration } \\ 58 & B_{2 \mathrm{u}} & 0.06 & 0.00 & \text { Libration } \\ 58 & A_{\mathrm{u}} & 0.00 & 0.00 & \text { Libration } \\ 71 & B_{1 \mathrm{u}} & 0.00 & 0.00 & \text { Libration } \\ & A_{\mathrm{g}} & 0.00 & 8.91 & \text { Libration }\end{array}$




$\begin{array}{lllll}74 & B_{1 \mathrm{~g}} & 0.00 & 97.62 & \text { Libration } \\ 75 & B_{2 \mathrm{~g}} & 0.00 & 0.00 & \text { Libration } \\ 78 & B_{3 \mathrm{~g}} & 0.00 & 123.32 & \text { Libration } \\ 104 & B_{1 \mathrm{u}} & 0.46 & 0.00 & \text { C-I in-phase out-of-plane bend } \\ 105 & B_{2 \mathrm{~g}} & 0.00 & 0.00 & \text { C-I in-phase out-of-plane bend } \\ 108 & B_{3 \mathrm{u}} & 1.36 & 0.00 & \text { C-I in-phase out-of-plane bend } \\ 109 & A_{\mathrm{g}} & 0.00 & 20.19 & \text { C-I in-phase out-of-plane bend } \\ 110 & A_{\mathrm{g}} & 0.00 & 336.42 & \text { C-I in-phase in-plane bend } \\ 110 & A_{\mathrm{u}} & 0.00 & 0.00 & \text { C-I in-phase out-of-plane bend } \\ 110 & B_{3 \mathrm{~g}} & 0.00 & 49.24 & \text { C-I in-phase out-of-plane bend } \\ 112 & B_{1 \mathrm{u}} & 0.73 & 0.00 & \text { C-I in-phase in-plane bend } \\ 113 & B_{1 \mathrm{~g}} & 0.00 & 0.00 & \text { C-I in-phase in-plane bend } \\ 113 & B_{2 \mathrm{~g}} & 0.00 & 223.16 & \text { C-I in-phase in-plane bend } \\ 114 & B_{2 \mathrm{u}} & 0.00 & 0.00 & \text { C-I in-phase out-of-plane bend } \\ 115 & B_{1 \mathrm{~g}} & 0.00 & 5.39 & \text { C-I in-phase out-of-plane bend } \\ & B_{3 \mathrm{u}} & 0.01 & 0.00 & \text { C-I in-phase in-plane bend }\end{array}$




$\begin{array}{lllll}117 & A_{\mathrm{u}} & 0.00 & 0.00 & \text { C-I in-phase in-plane bend } \\ 118 & B_{3 \mathrm{~g}} & 0.00 & 8.12 & \text { C-I in-phase in-plane bend } \\ 119 & B_{2 \mathrm{u}} & 1.06 & 0.00 & \text { C-I in-phase in-plane bend } \\ 184 & A_{\mathrm{u}} & 0.00 & 0.00 & \text { C-I symmetric stretch } \\ 185 & B_{3 \mathrm{~g}} & 0.00 & 3.63 & \text { C-I symmetric stretch } \\ 186 & B_{2 \mathrm{u}} & 2.60 & 0.00 & \text { C-I symmetric stretch } \\ 186 & B_{1 \mathrm{~g}} & 0.00 & 5.47 & \text { C-I symmetric stretch } \\ 187 & B_{1 \mathrm{u}} & 0.26 & 0.00 & \text { C-I symmetric stretch } \\ 187 & B_{2 \mathrm{~g}} & 0.00 & 326.63 & \text { C-I symmetric stretch } \\ 188 & B_{3 \mathrm{u}} & 2.22 & 0.00 & \text { C-I symmetric stretch } \\ 188 & A_{\mathrm{g}} & 0.00 & 608.29 & \text { C-I symmetric stretch } \\ 220 & B_{2 \mathrm{u}} & 0.12 & 0.00 & \text { C-I out-of-phase out-of-plane bend } \\ 221 & B_{3 \mathrm{u}} & 0.09 & 0.00 & \text { C-I out-of-phase out-of-plane bend } \\ 221 & B_{1 \mathrm{~g}} & 0.00 & 0.00 & \text { C-I out-of-phase out-of-plane bend } \\ 223 & A_{\mathrm{g}} & 0.00 & 33.43 & \text { C-I out-of-phase out-of-plane bend } \\ 22 & A_{\mathrm{u}} & 0.00 & 0.00 & \text { C-I out-of-phase out-of-plane bend }\end{array}$




\begin{tabular}{|c|c|c|c|c|}
\hline 225 & $B_{1 \mathrm{u}}$ & 0.21 & 0.00 & C-I out-of-phase out-of-plane bend \\
\hline 227 & $B_{3 g}$ & 0.00 & 0.00 & C-I out-of-phase out-of-plane bend \\
\hline 228 & $B_{2 g}$ & 0.00 & 46.49 & C-I out-of-phase out-of-plane bend \\
\hline 236 & $A_{\mathrm{g}}$ & 0.00 & 19.63 & $\mathrm{C}-\mathrm{I}$ out-of-phase in-plane bend \\
\hline 236 & $B_{1 \mathrm{u}}$ & 1.45 & 0.00 & C-I out-of-phase in-plane bend \\
\hline 236 & $B_{2 g}$ & 0.00 & 2.79 & C-I out-of-phase in-plane bend \\
\hline 237 & $B_{3 u}$ & 0.24 & 0.00 & C-I out-of-phase in-plane bend \\
\hline 240 & $A_{\mathrm{u}}$ & 0.00 & 0.00 & C-I out-of-phase in-plane bend \\
\hline 240 & $B_{3 g}$ & 0.00 & 33.85 & $\mathrm{C}-\mathrm{I}$ out-of-phase in-plane bend \\
\hline 241 & $B_{1 \mathrm{~g}}$ & 0.00 & 25.12 & C-I out-of-phase in-plane bend \\
\hline 242 & $B_{2 u}$ & 0.21 & 0.00 & C-I out-of-phase in-plane bend \\
\hline 360 & $B_{3 \mathrm{u}}$ & 14.46 & 0.00 & $\mathrm{C}-\mathrm{I}$ antisymmetric stretch \\
\hline 360 & $A_{\mathrm{g}}$ & 0.00 & 45.59 & C-I antisymmetric stretch \\
\hline 361 & $B_{2 \mathrm{u}}$ & 0.94 & 0.00 & $\mathrm{C}-\mathrm{I}$ antisymmetric stretch \\
\hline 361 & $B_{1 \mathrm{~g}}$ & 0.00 & 27.07 & C-I antisymmetric stretch \\
\hline 361 & $B_{1 \mathrm{u}}$ & 1.78 & 0.00 & C-I antisymmetric stretch \\
\hline
\end{tabular}




\begin{tabular}{|c|c|c|c|c|}
\hline 362 & $B_{2 \mathrm{~g}}$ & 0.00 & 0.00 & C-I antisymmetric stretch \\
\hline 362 & $A_{\mathrm{u}}$ & 0.00 & 0.00 & C-I antisymmetric stretch \\
\hline 363 & $B_{3 g}$ & 0.00 & 27.57 & $\mathrm{C}-\mathrm{I}$ antisymmetric stretch \\
\hline 449 & $B_{1 \mathrm{u}}$ & 246.89 & 0.00 & Out-of-plane ring deformation ( $\mathrm{C}-\mathrm{S}$ torsion) \\
\hline 450 & $B_{2 \mathrm{~g}}$ & 0.00 & 2.35 & Out-of-plane ring deformation ( $\mathrm{C}-\mathrm{S}$ torsion) \\
\hline 450 & $B_{3 u}$ & 104.55 & 0.00 & Out-of-plane ring deformation ( $\mathrm{C}-\mathrm{S}$ torsion) \\
\hline 451 & $A_{\mathrm{g}}$ & 0.00 & 1.85 & Out-of-plane ring deformation (C-S torsion) \\
\hline 451 & $A_{\mathrm{u}}$ & 0.00 & 0.00 & Out-of-plane ring deformation (C-S torsion) \\
\hline 453 & $B_{3 g}$ & 0.00 & 9.04 & Out-of-plane ring deformation ( $\mathrm{C}-\mathrm{S}$ torsion) \\
\hline 453 & $B_{2 u}$ & 0.67 & 0.00 & Out-of-plane ring deformation ( $\mathrm{C}-\mathrm{S}$ torsion) \\
\hline 454 & $B_{1 \mathrm{~g}}$ & 0.00 & 2.06 & Out-of-plane ring deformation ( $\mathrm{C}-\mathrm{S}$ torsion) \\
\hline 533 & $A_{\mathrm{u}}$ & 0.00 & 0.00 & $\mathrm{C} 2-\mathrm{C} 3$ torsion \\
\hline 534 & $B_{1 \mathrm{u}}$ & 1.42 & 0.00 & $\mathrm{C} 2-\mathrm{C} 3$ torsion \\
\hline 536 & $B_{1 \mathrm{~g}}$ & 0.00 & 0.00 & $\mathrm{C} 2-\mathrm{C} 3$ torsion \\
\hline 537 & $B_{2 \mathrm{u}}$ & 0.03 & 0.00 & $\mathrm{C} 2-\mathrm{C} 3$ torsion \\
\hline 537 & $A_{\mathrm{g}}$ & 0.00 & 10.55 & $\mathrm{C} 2-\mathrm{C} 3$ torsion \\
\hline
\end{tabular}




$\begin{array}{lllll}538 & B_{3 \mathrm{u}} & 0.06 & 0.00 & \mathrm{C} 2-\mathrm{C} 3 \text { torsion } \\ 541 & B_{3 \mathrm{~g}} & 0.00 & 0.00 & \mathrm{C} 2-\mathrm{C} 3 \text { torsion } \\ 542 & B_{2 \mathrm{~g}} & 0.00 & 4.70 & \mathrm{C} 2-\mathrm{C} 3 \text { torsion } \\ 631 & B_{3 \mathrm{~g}} & 0.00 & 12.37 & \mathrm{C} 1-\mathrm{S}+\mathrm{C} 4-\mathrm{S} \text { in-phase stretch } \\ 631 & B_{2 \mathrm{~g}} & 0.00 & 154.80 & \mathrm{C} 1-\mathrm{S}+\mathrm{C} 4-\mathrm{S} \text { in-phase stretch } \\ 632 & A_{\mathrm{u}} & 0.00 & 0.00 & \mathrm{C} 1-\mathrm{S}+\mathrm{C} 4-\mathrm{S} \text { in-phase stretch } \\ 632 & A_{\mathrm{g}} & 0.00 & 3108.77 & \mathrm{C} 1-\mathrm{S}+\mathrm{C} 4-\mathrm{S} \text { in-phase stretch } \\ 632 & B_{1 \mathrm{u}} & 3.55 & 0.00 & \mathrm{C} 1-\mathrm{S}+\mathrm{C} 4-\mathrm{S} \text { in-phase stretch } \\ 633 & B_{1 \mathrm{~g}} & 0.00 & 0.00 & \mathrm{C} 1-\mathrm{S}+\mathrm{C} 4-\mathrm{S} \text { in-phase stretch } \\ 634 & B_{3 \mathrm{u}} & 0.38 & 0.00 & \mathrm{C} 1-\mathrm{S}+\mathrm{C} 4-\mathrm{S} \text { in-phase stretch } \\ 636 & B_{2 \mathrm{u}} & 1.86 & 0.00 & \mathrm{C} 1-\mathrm{S}+\mathrm{C} 4-\mathrm{S} \text { in-phase stretch } \\ 717 & A_{\mathrm{g}} & 0.00 & 2.74 & \mathrm{C} 1-\mathrm{S}+\mathrm{C} 4-\mathrm{S} \text { out-of-phase stretch } \\ 717 & B_{3 \mathrm{u}} & 64.90 & 0.00 & \mathrm{C} 1-\mathrm{S}+\mathrm{C} 4-\mathrm{S} \text { out-of-phase stretch } \\ 717 & B_{2 \mathrm{u}} & 1.08 & 0.00 & \mathrm{C} 1-\mathrm{S}+\mathrm{C} 4-\mathrm{S} \text { out-of-phase stretch } \\ 717 & B_{1 \mathrm{~g}} & 0.00 & 52.20 & \mathrm{C} 1-\mathrm{S}+\mathrm{C} 4-\mathrm{S} \text { out-of-phase stretch } \\ 717 & B_{3 \mathrm{~g}} & 0.00 & 11.09 & \mathrm{C} 1-\mathrm{S}+\mathrm{C} 4-\mathrm{S} \text { out-of-phase stretch }\end{array}$




\begin{tabular}{|c|c|c|c|c|}
\hline 717 & $B_{2 g}$ & 0.00 & 10.27 & $\mathrm{C} 1-\mathrm{S}+\mathrm{C} 4-\mathrm{S}$ out-of-phase stretch \\
\hline 718 & $A_{\mathrm{u}}$ & 0.00 & 0.00 & $\mathrm{C} 1-\mathrm{S}+\mathrm{C} 4-\mathrm{S}$ out-of-phase stretch \\
\hline 718 & $B_{1 \mathrm{u}}$ & 24.34 & 0.00 & $\mathrm{C} 1-\mathrm{S}+\mathrm{C} 4-\mathrm{S}$ out-of-phase stretch \\
\hline 771 & $B_{1 \mathrm{u}}$ & 498.48 & 0.00 & In-phase $\mathrm{C}-\mathrm{H}$ out-of-plane bend \\
\hline 771 & $A_{\mathrm{u}}$ & 0.00 & 0.00 & In-phase $\mathrm{C}-\mathrm{H}$ out-of-plane bend \\
\hline 773 & $B_{3 \mathrm{u}}$ & 309.30 & 0.00 & In-phase $\mathrm{C}-\mathrm{H}$ out-of-plane bend \\
\hline 774 & $B_{2 u}$ & 0.11 & 0.00 & In-phase $\mathrm{C}-\mathrm{H}$ out-of-plane bend \\
\hline 777 & $A_{\mathrm{g}}$ & 0.00 & 9.99 & In-phase $\mathrm{C}-\mathrm{H}$ out-of-plane bend \\
\hline 777 & $B_{1 \mathrm{~g}}$ & 0.00 & 7.84 & In-phase $\mathrm{C}-\mathrm{H}$ out-of-plane bend \\
\hline 782 & $B_{2 \mathrm{~g}}$ & 0.00 & 16.46 & In-phase $\mathrm{C}-\mathrm{H}$ out-of-plane bend \\
\hline 782 & $B_{3 \mathrm{~g}}$ & 0.00 & 0.00 & In-phase $\mathrm{C}-\mathrm{H}$ out-of-plane bend \\
\hline 862 & $A_{\mathrm{u}}$ & 0.00 & 0.00 & Out-of-phase C-H out-of-plane bend \\
\hline 862 & $B_{1 \mathrm{u}}$ & 3.08 & 0.00 & Out-of-phase C-H out-of-plane bend \\
\hline 867 & $B_{1 \mathrm{~g}}$ & 0.00 & 0.00 & Out-of-phase $\mathrm{C}-\mathrm{H}$ out-of-plane bend \\
\hline 867 & $A_{\mathrm{g}}$ & 0.00 & 24.26 & Out-of-phase $\mathrm{C}-\mathrm{H}$ out-of-plane bend \\
\hline 874 & $B_{2 u}$ & 6.30 & 0.00 & Out-of-phase C-H out-of-plane bend \\
\hline
\end{tabular}




\begin{tabular}{|c|c|c|c|c|}
\hline 874 & $B_{3 \mathrm{u}}$ & 1.97 & 0.00 & Out-of-phase C-H out-of-plane bend \\
\hline 878 & $B_{3 \mathrm{~g}}$ & 0.00 & 6.43 & Out-of-phase C-H out-of-plane bend \\
\hline 878 & $B_{2 g}$ & 0.00 & 15.14 & Out-of-phase $\mathrm{C}-\mathrm{H}$ out-of-plane bend \\
\hline 910 & $B_{2 \mathrm{u}}$ & 161.64 & 0.00 & $\begin{array}{l}\text { Symmetric in-plane ring deformation } \\
\text { (in-phase } \mathrm{C} 1-\mathrm{C} 2-\mathrm{C} 3+\mathrm{C} 4-\mathrm{C} 3-\mathrm{C} 2 \text { bend) }\end{array}$ \\
\hline 911 & $B_{3 g}$ & 0.00 & 22.89 & $\begin{array}{l}\text { Symmetric in-plane ring deformation } \\
\text { (in-phase } \mathrm{C} 1-\mathrm{C} 2-\mathrm{C} 3+\mathrm{C} 4-\mathrm{C} 3-\mathrm{C} 2 \text { bend) }\end{array}$ \\
\hline 912 & $B_{1 \mathrm{~g}}$ & 0.00 & 11.00 & $\begin{array}{l}\text { Symmetric in-plane ring deformation } \\
\text { (in-phase } \mathrm{C} 1-\mathrm{C} 2-\mathrm{C} 3+\mathrm{C} 4-\mathrm{C} 3-\mathrm{C} 2 \text { bend) }\end{array}$ \\
\hline 912 & $A_{\mathrm{u}}$ & 0.00 & 0.00 & $\begin{array}{l}\text { Symmetric in-plane ring deformation } \\
\text { (in-phase } \mathrm{C} 1-\mathrm{C} 2-\mathrm{C} 3+\mathrm{C} 4-\mathrm{C} 3-\mathrm{C} 2 \text { bend) }\end{array}$ \\
\hline 913 & $B_{3 \mathrm{u}}$ & 1.05 & 0.00 & $\begin{array}{l}\text { Symmetric in-plane ring deformation } \\
\text { (in-phase } \mathrm{C} 1-\mathrm{C} 2-\mathrm{C} 3+\mathrm{C} 4-\mathrm{C} 3-\mathrm{C} 2 \text { bend) }\end{array}$ \\
\hline 914 & $B_{1 \mathrm{u}}$ & 1.95 & 0.00 & $\begin{array}{l}\text { Symmetric in-plane ring deformation } \\
\text { (in-phase } \mathrm{C} 1-\mathrm{C} 2-\mathrm{C} 3+\mathrm{C} 4-\mathrm{C} 3-\mathrm{C} 2 \text { bend) }\end{array}$ \\
\hline 914 & $B_{2 \mathrm{~g}}$ & 0.00 & 618.27 & $\begin{array}{l}\text { Symmetric in-plane ring deformation } \\
\text { (in-phase } \mathrm{C} 1-\mathrm{C} 2-\mathrm{C} 3+\mathrm{C} 4-\mathrm{C} 3-\mathrm{C} 2 \text { bend) }\end{array}$ \\
\hline 914 & $A_{\mathrm{g}}$ & 0.00 & 600.22 & $\begin{array}{l}\text { Symmetric in-plane ring deformation } \\
\text { (in-phase } \mathrm{C} 1-\mathrm{C} 2-\mathrm{C} 3+\mathrm{C} 4-\mathrm{C} 3-\mathrm{C} 2 \text { bend) }\end{array}$ \\
\hline 931 & $B_{1 \mathrm{~g}}$ & 0.00 & 5.90 & $\begin{array}{l}\text { Antisymmetric in-plane ring deformation } \\
\text { (out-of-phase } \mathrm{C} 1-\mathrm{C} 2-\mathrm{C} 3+\mathrm{C} 4-\mathrm{C} 3-\mathrm{C} 2 \text { bend) }\end{array}$ \\
\hline 931 & $B_{3 \mathrm{~g}}$ & 0.00 & 0.00 & $\begin{array}{l}\text { Antisymmetric in-plane ring deformation } \\
\text { (out-of-phase } \mathrm{C} 1-\mathrm{C} 2-\mathrm{C} 3+\mathrm{C} 4-\mathrm{C} 3-\mathrm{C} 2 \text { bend) }\end{array}$ \\
\hline 932 & $B_{2 \mathrm{u}}$ & 1.70 & 0.00 & $\begin{array}{l}\text { Antisymmetric in-plane ring deformation } \\
\text { (out-of-phase } \mathrm{C} 1-\mathrm{C} 2-\mathrm{C} 3+\mathrm{C} 4-\mathrm{C} 3-\mathrm{C} 2 \text { bend) }\end{array}$ \\
\hline 932 & $A_{\mathrm{g}}$ & 0.00 & 11.65 & $\begin{array}{l}\text { Antisymmetric in-plane ring deformation } \\
\text { (out-of-phase } \mathrm{C} 1-\mathrm{C} 2-\mathrm{C} 3+\mathrm{C} 4-\mathrm{C} 3-\mathrm{C} 2 \text { bend) }\end{array}$ \\
\hline 932 & $A_{\mathrm{u}}$ & 0.00 & 0.00 & $\begin{array}{l}\text { Antisymmetric in-plane ring deformation } \\
\text { (out-of-phase } \mathrm{C} 1-\mathrm{C} 2-\mathrm{C} 3+\mathrm{C} 4-\mathrm{C} 3-\mathrm{C} 2 \text { bend) }\end{array}$ \\
\hline
\end{tabular}




\begin{tabular}{|c|c|c|c|c|}
\hline 932 & $B_{3 \mathrm{u}}$ & 218.37 & 0.00 & $\begin{array}{l}\text { Antisymmetric in-plane ring deformation } \\
\text { (out-of-phase } \mathrm{C} 1-\mathrm{C} 2-\mathrm{C} 3+\mathrm{C} 4-\mathrm{C} 3-\mathrm{C} 2 \text { bend) }\end{array}$ \\
\hline 934 & $B_{2 g}$ & 0.00 & 0.00 & $\begin{array}{l}\text { Antisymmetric in-plane ring deformation } \\
\text { (out-of-phase } \mathrm{C} 1-\mathrm{C} 2-\mathrm{C} 3+\mathrm{C} 4-\mathrm{C} 3-\mathrm{C} 2 \text { bend) }\end{array}$ \\
\hline 935 & $B_{1 \mathrm{u}}$ & 46.81 & 0.00 & $\begin{array}{l}\text { Antisymmetric in-plane ring deformation } \\
\text { (out-of-phase } \mathrm{C} 1-\mathrm{C} 2-\mathrm{C} 3+\mathrm{C} 4-\mathrm{C} 3-\mathrm{C} 2 \text { bend) }\end{array}$ \\
\hline 1054 & $B_{1 \mathrm{~g}}$ & 0.00 & 13.66 & $\mathrm{C}-\mathrm{H}$ in-plane symmetric bend \\
\hline 1055 & $A_{\mathrm{u}}$ & 0.00 & 0.00 & $\mathrm{C}-\mathrm{H}$ in-plane symmetric bend \\
\hline 1055 & $A_{\mathrm{g}}$ & 0.00 & 416.56 & $\mathrm{C}-\mathrm{H}$ in-plane symmetric bend \\
\hline 1056 & $B_{1 \mathrm{u}}$ & 20.39 & 0.00 & $\mathrm{C}-\mathrm{H}$ in-plane symmetric bend \\
\hline 1060 & $B_{3 \mathrm{~g}}$ & 0.00 & 19.89 & $\mathrm{C}-\mathrm{H}$ in-plane symmetric bend \\
\hline 1061 & $B_{2 g}$ & 0.00 & 43.68 & $\mathrm{C}-\mathrm{H}$ in-plane symmetric bend \\
\hline 1062 & $B_{2 u}$ & 26.24 & 0.00 & $\mathrm{C}-\mathrm{H}$ in-plane symmetric bend \\
\hline 1063 & $B_{3 \mathrm{u}}$ & 2.42 & 0.00 & $\mathrm{C}-\mathrm{H}$ in-plane symmetric bend \\
\hline 1187 & $B_{1 \mathrm{u}}$ & 72.16 & 0.00 & $\mathrm{C}-\mathrm{H}$ in-plane antisymmetric bend \\
\hline 1187 & $A_{\mathrm{u}}$ & 0.00 & 0.00 & $\mathrm{C}-\mathrm{H}$ in-plane antisymmetric bend \\
\hline 1187 & $B_{3 \mathrm{u}}$ & 84.57 & 0.00 & $\mathrm{C}-\mathrm{H}$ in-plane antisymmetric bend \\
\hline 1187 & $B_{2 u}$ & 6.49 & 0.00 & $\mathrm{C}-\mathrm{H}$ in-plane antisymmetric bend \\
\hline 1187 & $A_{\mathrm{g}}$ & 0.00 & 19.26 & $\mathrm{C}-\mathrm{H}$ in-plane antisymmetric bend \\
\hline
\end{tabular}




$\begin{array}{lllll}1187 & B_{1 \mathrm{~g}} & 0.00 & 150.45 & \mathrm{C}-\mathrm{H} \text { in-plane antisymmetric bend } \\ 1187 & B_{3 \mathrm{~g}} & 0.00 & 133.95 & \mathrm{C}-\mathrm{H} \text { in-plane antisymmetric bend } \\ 1188 & B_{2 \mathrm{~g}} & 0.00 & 2.61 & \mathrm{C}-\mathrm{H} \text { in-plane antisymmetric bend } \\ 1278 & B_{2 \mathrm{u}} & 0.47 & 0.00 & \mathrm{C} 1-\mathrm{C} 2+\mathrm{C} 3-\mathrm{C} 4 \text { in-phase stretch } \\ 1279 & B_{3 \mathrm{~g}} & 0.00 & 54.82 & \mathrm{C} 1-\mathrm{C} 2+\mathrm{C} 3-\mathrm{C} 4 \text { in-phase stretch } \\ 1279 & A_{\mathrm{u}} & 0.00 & 0.00 & \mathrm{C} 1-\mathrm{C} 2+\mathrm{C} 3-\mathrm{C} 4 \text { in-phase stretch } \\ 1280 & B_{2 \mathrm{~g}} & 0.00 & 4.23 & \mathrm{C} 1-\mathrm{C} 2+\mathrm{C} 3-\mathrm{C} 4 \text { in-phase stretch } \\ 1280 & B_{3 \mathrm{u}} & 3.46 & 0.00 & \mathrm{C} 1-\mathrm{C} 2+\mathrm{C} 3-\mathrm{C} 4 \text { in-phase stretch } \\ 1280 & B_{1 \mathrm{u}} & 4.99 & 0.00 & \mathrm{C} 1-\mathrm{C} 2+\mathrm{C} 3-\mathrm{C} 4 \text { in-phase stretch } \\ 1280 & B_{1 \mathrm{~g}} & 0.00 & 2.41 & \mathrm{C} 1-\mathrm{C} 2+\mathrm{C} 3-\mathrm{C} 4 \text { in-phase stretch } \\ 1281 & A_{\mathrm{g}} & 0.00 & 1936.40 & \mathrm{C} 1-\mathrm{C} 2+\mathrm{C} 3-\mathrm{C} 4 \text { in-phase stretch } \\ 1379 & B_{1 \mathrm{u}} & 14.08 & 0.00 & \mathrm{C} 2-\mathrm{C} 3 \text { stretch } \\ 1379 & A_{\mathrm{g}} & 0.00 & 6622.85 & \mathrm{C} 2-\mathrm{C} 3 \text { stretch } \\ 1379 & A_{\mathrm{u}} & 0.00 & 0.00 & \mathrm{C} 2-\mathrm{C} 3 \text { stretch } \\ 1379 & B_{1 \mathrm{~g}} & 0.00 & 73.40 & \mathrm{C} 2-\mathrm{C} 3 \text { stretch } \\ 1380 & B_{3 \mathrm{~g}} & 0.00 & 0.00 & \mathrm{C} 2-\mathrm{C} 3 \text { stretch }\end{array}$




$\begin{array}{lllll}1380 & B_{2 \mathrm{~g}} & 0.00 & 1492.25 & \text { C2-C3 stretch } \\ 1381 & B_{2 \mathrm{u}} & 401.10 & 0.00 & \text { C2-C3 stretch } \\ 1383 & B_{3 \mathrm{u}} & 4.29 & 0.00 & \mathrm{C} 2-\mathrm{C} 3 \text { stretch } \\ 1475 & A_{\mathrm{u}} & 0.00 & 0.00 & \mathrm{C} 1-\mathrm{C} 2+\mathrm{C} 3-\mathrm{C} 4 \text { out-of-phase stretch } \\ 1475 & B_{1 \mathrm{u}} & 48.16 & 0.00 & \mathrm{C} 1-\mathrm{C} 2+\mathrm{C} 3-\mathrm{C} 4 \text { out-of-phase stretch } \\ 1475 & B_{1 \mathrm{~g}} & 0.00 & 4.98 & \mathrm{C} 1-\mathrm{C} 2+\mathrm{C} 3-\mathrm{C} 4 \text { out-of-phase stretch } \\ 1475 & A_{\mathrm{g}} & 0.00 & 9.98 & \mathrm{C} 1-\mathrm{C} 2+\mathrm{C} 3-\mathrm{C} 4 \text { out-of-phase stretch } \\ 1476 & B_{3 \mathrm{u}} & 79.26 & 0.00 & \mathrm{C} 1-\mathrm{C} 2+\mathrm{C} 3-\mathrm{C} 4 \text { out-of-phase stretch } \\ 1476 & B_{2 \mathrm{u}} & 1.47 & 0.00 & \text { C1-C2 + C3-C4 out-of-phase stretch } \\ 1476 & B_{3 \mathrm{~g}} & 0.00 & 6.12 & \text { C1-C2 + C3-C4 out-of-phase stretch } \\ 1476 & B_{2 \mathrm{~g}} & 0.00 & 9.06 & \text { C1-C2 + C3-C4 out-of-phase stretch } \\ 3122 & B_{3 \mathrm{u}} & 24.71 & 0.00 & \text { Out-of-phase C-H stretch } \\ 3122 & B_{2 \mathrm{u}} & 0.00 & 0.00 & \text { Out-of-phase C-H stretch } \\ 3122 & A_{\mathrm{u}} & 0.00 & 0.00 & \text { Out-of-phase C-H stretch } \\ 3123 & B_{3 \mathrm{~g}} & 0.00 & 1344.38 & \text { Out-of-phase C-H stretch } \\ 3123 & B_{2 \mathrm{~g}} & 0.00 & 31.55 & \text { Out-of-phase C-H stretch }\end{array}$




$\begin{array}{lcccc}3123 & A_{\mathrm{g}} & 0.00 & 58.01 & \text { Out-of-phase C-H stretch } \\ 3123 & B_{1 \mathrm{~g}} & 0.00 & 2221.87 & \text { Out-of-phase C-H stretch } \\ 3132 & B_{2 \mathrm{u}} & 185.34 & 0.00 & \text { Out-of-phase C-H stretch } \\ 3132 & B_{3 \mathrm{u}} & 0.00 & 0.00 & \text { In-phase C-H stretch } \\ 3133 & A_{\mathrm{u}} & 0.00 & 0.00 & \text { In-phase C-H stretch } \\ 3133 & B_{1 \mathrm{u}} & 18.64 & 0.00 & \text { In-phase C-H stretch } \\ 3133 & B_{3 \mathrm{~g}} & 0.00 & 654.29 & \text { In-phase C-H stretch } \\ 3133 & B_{2 \mathrm{~g}} & 0.00 & 377.38 & \text { In-phase C-H stretch } \\ 3133 & A_{\mathrm{g}} & 0.00 & 13551.08 & \text { In-phase C-H stretch } \\ 3133 & B_{1 \mathrm{~g}} & 0.00 & 64.64 & \text { In-phase C-H stretch }\end{array}$

$\dagger$ The symmetry allows the translations and librations to mix, thus the description reflects the predominant motion. 


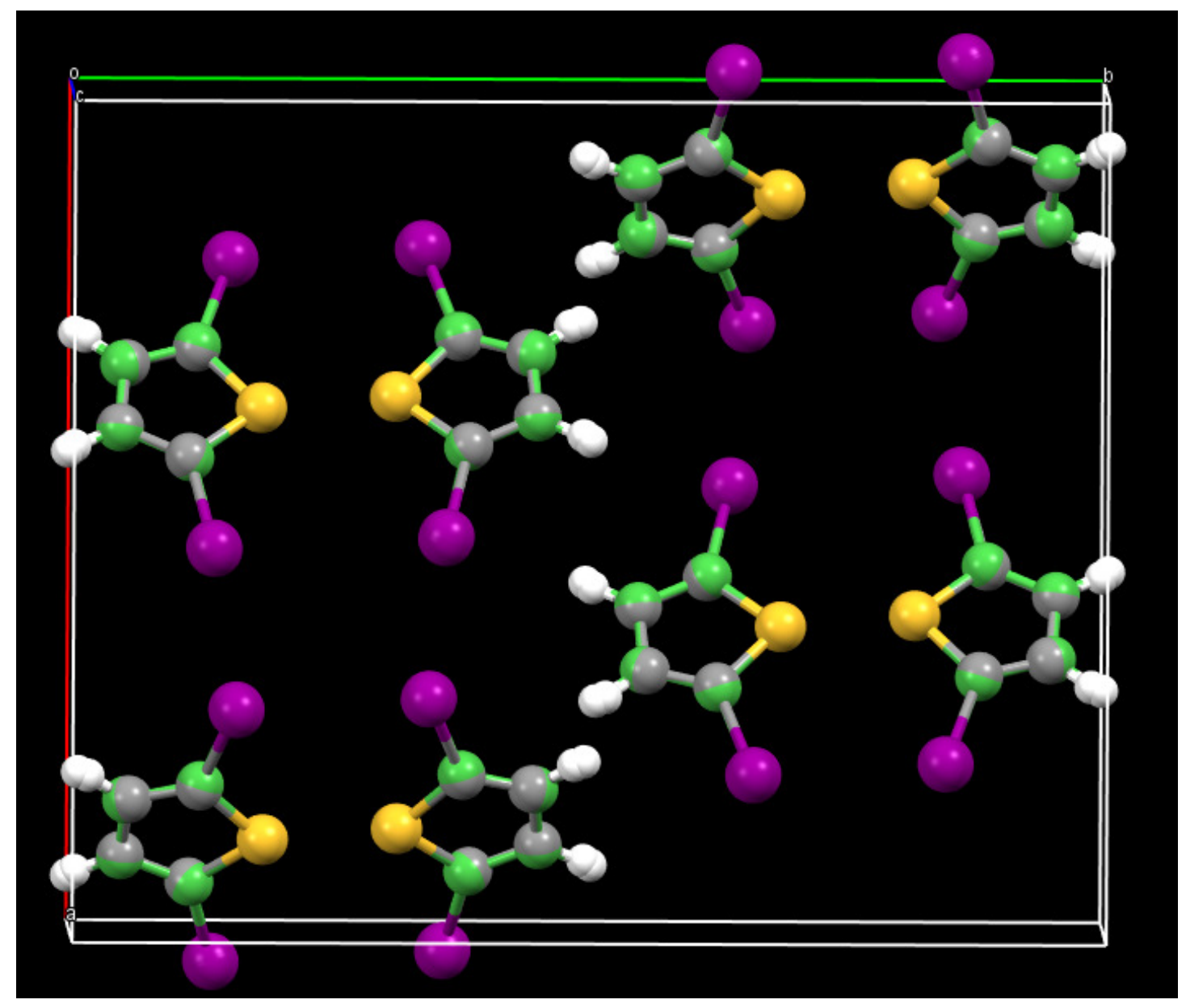

Figure S1: Comparison of the experimental and CASTEP optimised structure of 2,5-

diiodothiophene. The grey atoms are those of the experimental structure and the green for the calculated structure, the iodine (purple) and sulfur (yellow) are coincident in both structures. As noted in the text, the only significant difference is for the $\mathrm{C}-\mathrm{H}$ bond distance which, as is usually found, is underestimated in the X-ray determination. 


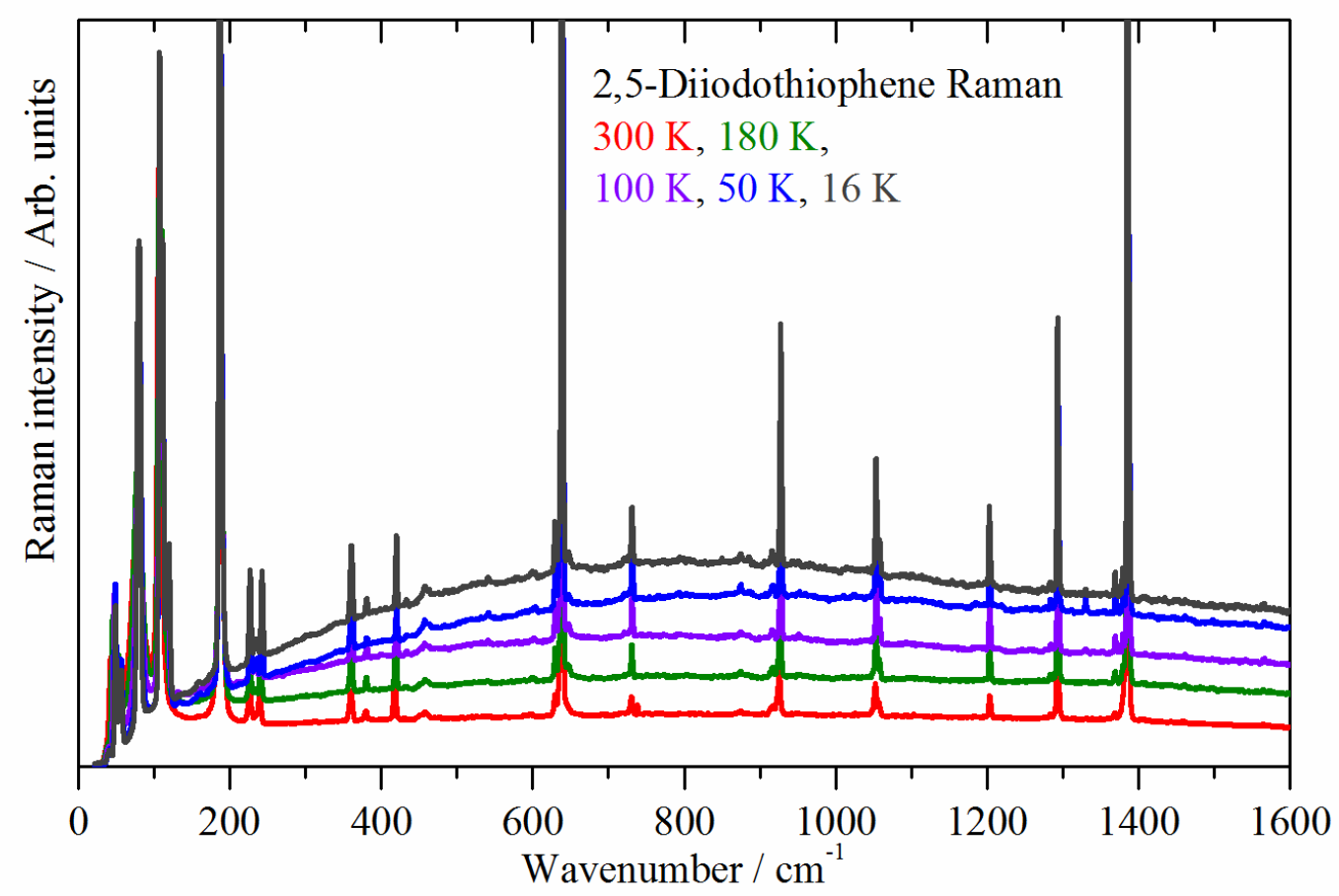

Figure S2: Extended range $\left(30-1800 \mathrm{~cm}^{-1}\right)$ variable temperature Raman spectra of 2,5diiodothiophene.

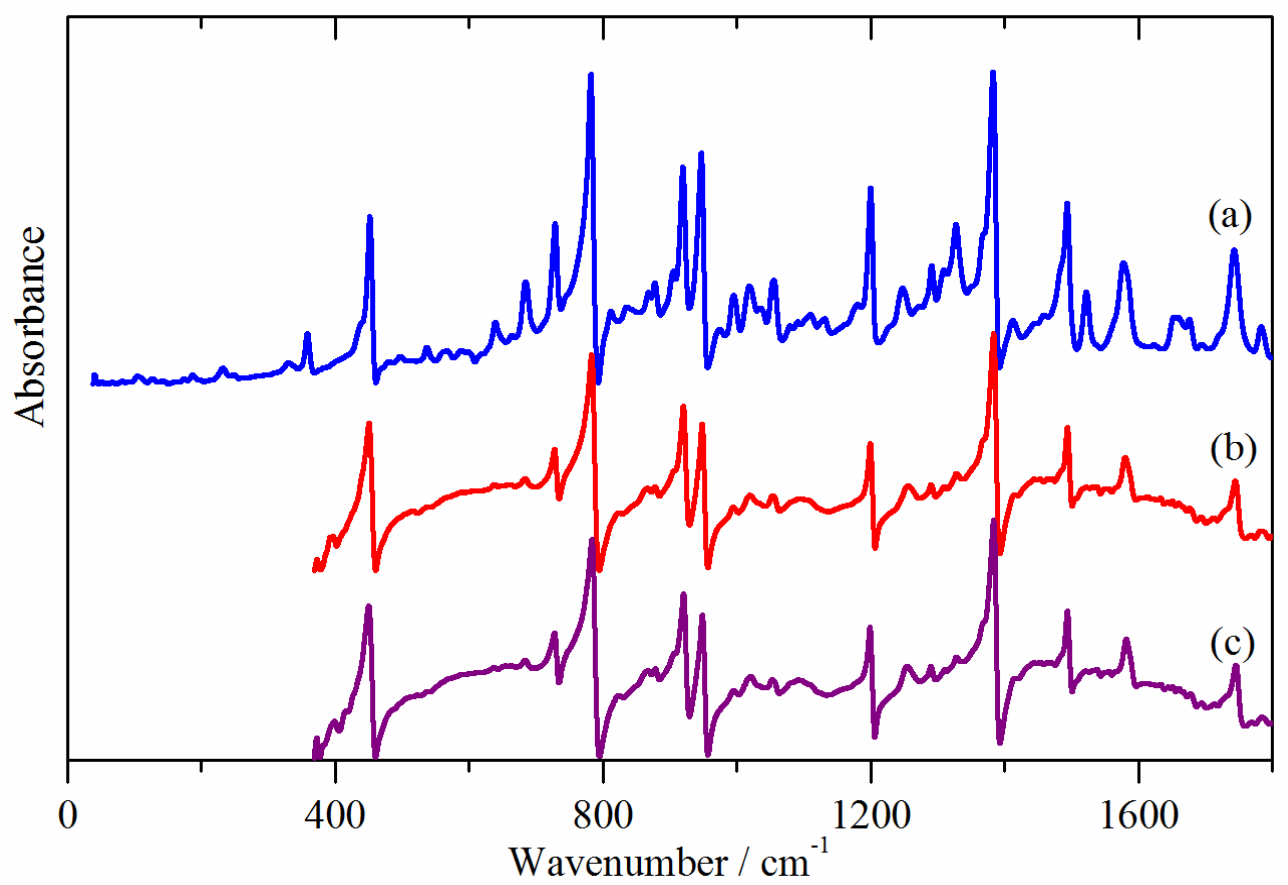

Figure S3: Infrared spectra of 2,5-diiodothiophene at: (a) $300 \mathrm{~K}$, (b) $180 \mathrm{~K}$ and (c) $111 \mathrm{~K}$. 